IZA DP No. 8263

Behavioural Labour Economics:

Advances and Future Directions

Thomas Dohmen

June 2014 


\title{
Behavioural Labour Economics: Advances and Future Directions
}

\author{
Thomas Dohmen \\ University of Bonn, Maastricht University, \\ $R O A, I Z A$ and DIW
}
Discussion Paper No. 8263
June 2014

\author{
IZA \\ P.O. Box 7240 \\ 53072 Bonn \\ Germany \\ Phone: +49-228-3894-0 \\ Fax: +49-228-3894-180 \\ E-mail: iza@iza.org
}

Any opinions expressed here are those of the author(s) and not those of IZA. Research published in this series may include views on policy, but the institute itself takes no institutional policy positions. The IZA research network is committed to the IZA Guiding Principles of Research Integrity.

The Institute for the Study of Labor (IZA) in Bonn is a local and virtual international research center and a place of communication between science, politics and business. IZA is an independent nonprofit organization supported by Deutsche Post Foundation. The center is associated with the University of Bonn and offers a stimulating research environment through its international network, workshops and conferences, data service, project support, research visits and doctoral program. IZA engages in (i) original and internationally competitive research in all fields of labor economics, (ii) development of policy concepts, and (iii) dissemination of research results and concepts to the interested public.

IZA Discussion Papers often represent preliminary work and are circulated to encourage discussion. Citation of such a paper should account for its provisional character. A revised version may be available directly from the author. 


\section{ABSTRACT \\ Behavioural Labour Economics: Advances and Future Directions ${ }^{1}$}

In the past decades, behavioural economics has become an influential and important field of economics. Interest in behavioural economics derives from unease with standard economic models that are based on restrictive assumptions, which confine the nature of human motivation. Although Adam Smith, the founding father of modern economics, had highlighted the multitude of psychological motives that drive human behaviour, and despite the fact that many influential economists thereafter believed in tenets of modern behavioural economics, the homo economicus assumption became prevalent, until this construct was challenged by compelling evidence on social, cognitive and emotional factors that drive decision-making and social interaction. Since human interaction is germane to labour markets, one would expect behavioural economics to be highly relevant for labour economics. This paper gauges whether and how behavioural economics has left its mark on labour economics, considers the timing and structure of this development, and contemplates its future impact on labour economics.

JEL Classification: J00, J01, D03

Keywords: behavioural economics, labour economics, behavioural labour economics

Corresponding author:

Thomas Dohmen

University of Bonn

Adenauerallee 24-42

53113 Bonn

Germany

E-mail: tdohmen@uni-bonn.de

\footnotetext{
1 This paper was prepared for the special issue of Labour Economics to commemorate the 25th anniversary of the European Association of Labour Economists (EALE). I am grateful to Armin Falk, Joop Hartog, David Huffman, Sebastian Kube, Rudolf Winter-Ebmer and participants at the EALE 2013 conference in Torino for valuable comments and discussions. Research assistance by Leo Becker, Laura Breitkopf and Geraldine Reichard is much appreciated. My greatest thanks go to Joop Hartog and Jules Theeuwes for initiating this special issue.
} 


\section{Introduction}

In the past decades, behavioural economics has emerged as an influential and important field of economics. In this essay, I will assess its implications for labour economics by taking stock of its impact on the field in the past decades. I document that behavioural economics has profoundly affected the way that labour economists think about the questions and challenges in labour economics. This is evident from several path-breaking publications in major economic journals. It is also revealed by a noticeable shift in attention of members of the European Association of Labour Economists (EALE) during its first 25 years of existence towards new questions that are increasingly studied by incorporating insights from behavioural economics and personality psychology. Labour economists have also become somewhat more receptive to the use of experimental methods, which were largely developed in the field of behavioural economics ${ }^{2}$. This development becomes visible upon an examination of session titles and topics of papers presented at EALE conferences. It also reflected by the themes of articles published in the association's journal Labour Economics from its launch in 1993 until today.

The behavioural economics approach deviates fundamentally from the mainstream model regarding assumptions about the nature of human motivation. Although its application to the analysis of labour markets has what it takes to revolutionize labour economics, the development over the past decades is more adequately described as a reform. It has neither marginalized the use of neoclassical concepts in the analysis of labour markets, nor has it led to a division of the field (c.f., Berg, 2006). This might be partly due to the fact that labour economists were initially not particularly receptive to new insights and ideas from behavioural economics. Labour economists' conservatism might stem from the fact that the mainstream model offers a simple and powerful tool to analyse a range of questions in labour economics. Impulses for incorporating various insights from behavioural economics often came from non-labour economists. This often led to fierce debates that gained momentum when well-established labour economists challenged the criticism from behavioural economists. Ideas and concepts from behavioural economics were accepted by labour economists when overwhelming evidence on labour market outcomes and behaviour could not be reconciled with the standard model or when prominent labour economists acted on the suggestions of behavioural economists. When labour economists incorporated insights from behavioural economics, they did so by enriching the standard model rather than abandoning it. ${ }^{3}$ Over time, many

\footnotetext{
${ }^{2}$ I would like to stress that one should not equate behavioural economics and experimental economics. The fact that the terms are sometimes confusingly used as equivalents might stem from the fact that the branch of behavioural economics has strongly relied on experimental methods.

${ }^{33}$ This approach of not abandoning the standard model altogether is heavily criticized by Berg and Gigerenzer (2010).
} 
ideas have become mainstream, which testifies to the impact of behavioural economics on labour economics.

I will exemplify when, how and why insights from behavioural economics have been adopted in labour economics. I will illustrate how this process involved the development of new (empirical) methods, a focus on particular topics and a stronger focus on micro labour issues. ${ }^{4}$ The latter is in accordance with the fact that the acknowledgment of a psychologically more complete view of human nature has a particular strong bearing on individual decision making (e.g., individual labour supply decisions) and human interaction (e.g., in principal-agent relationships or interaction among workers). While the influence of behavioural economics on macroeconomic labour market research is lagging behind, future progress is particularly promising in search and matching models.

The remainder of the paper is structured as follows. Section 2 summarizes important developments in behavioural economics that seem to be relevant for the analysis of labour issues. Section 3 provides a subjective view of the impact of behavioural economics on labour economics. It discusses why and how labour economists became interested in the application of methods from behavioural economics using as examples some specific strands of the literature. It also identifies topics and research questions that could profit substantially from behavioural economics. Section 4 zooms in at developments within the EALE-network, focusing in particular on trends in topics addressed at EALE conferences and papers published in Labour Economics. Section 5 appraises the policy relevance of these developments. Section 6 concludes.

\section{The emergence of behavioural economics as a field}

The term behavioural economics refers to the research area that studies the link between psychology and economics (c.f., Mullainathan and Thaler, 2001; Gul, 2008; DellaVigna, 2009). There is no unique definition of behavioural economics. Instead of defining what behavioural economics is, many authors rather describe what behavioural economists do (see, e.g., Camerer and Loewenstein, 2004; Thaler and Mullainathan, 2008; Weber and Dawes, 2010; Angner and Loewenstein, 2012). ${ }^{5}$ A

\footnotetext{
${ }^{4}$ Labour economists have traditionally been rooted in microeconomics. Yet, the focus in the late 1980 s was more on (the microfoundations) of aggregate labour market outcomes, which is, for example, reflected by a strong interest in (the determinants of) aggregate unemployment in this period.

${ }^{5}$ According to Angner and Loewenstein (2012), the term "behavioral economics" was already used in the late 1950s. Nowadays it refers to "the attempt to increase the explanatory and predictive power of economic theory by providing it with more psychologically plausible foundation." (Angner and Loewenstein (2012, p. 642). Camerer and Loewenstein $(2004$, p. 3) explain that "[b]ehavioral economics increases the explanatory power of economics by providing it with more realistic psychological foundations." They elucidate that "[a]t the core of behavioral economics is the conviction that increasing the realism of the psychological underpinnings of economic analysis will improve economics on its own terms --generating theoretical insights, making better
} 
common element of most of these definitions is that behavioural economics uses insights from psychology to investigate human decision making that is at odds with mainstream economic models, which postulate a rational, selfish, forward-looking utility maximizing agent, also known as homo economicus. ${ }^{6}$ One is thus inclined to say that the field of modern behavioural economics emerged in reaction to the mainstream model. In that sense, the strong interest in behavioural economics is a reflection of the influence and power of this simple framework which emerged from neoclassical economics in the $20^{\text {th }}$ century.

In any case, the attention that behavioural economics presently attracts derives from unease with standard economic models that constrain economists' reflections to this "very narrow and empirically questionable view of human motivation" (Fehr and Falk, 2002, p. 687). Some of these assumptions were initially either made to simplify economic models (c.f., Persky, 1995), or to keep mathematical representations of these models tractable, while building on assumptions that satisfy important axioms (see also Weintraub, 2002). ${ }^{7}$ But over time, the profession internalized the idea of the representative agent, who is risk neutral, forward-looking, time-consistent, selfish and rational. ${ }^{8}$ This might seem surprising in light of the fact that generations of economists had been well aware that human nature encompasses many more facets than that of homo economicus. Adam Smith, for example, had already portrayed a more comprehensive concept of human nature in The Theory of Moral Sentiment:

"How selfish soever man may be supposed, there are evidently some principles in his nature, which interest him in the fortune of others, and render their happiness necessary to him, though he derives nothing from it except the pleasure of seeing it." (Smith, 1759; [1981], p. 9)

As Ashraf, Camerer and Loewenstein (2005) elucidate, Smith had provided an account of psychological explanations of individual behaviour in The Theory of Moral Sentiments that "anticipates a wide range of insights regarding phenomena [...] that have been the focus of modern behavioural economics." [Ashraf, Camerer and Loewenstein (2005, p. 132).] Still, the mainstream

predictions of field phenomena, and suggesting better policy." Camerer and Loewenstein (2004, p. 3). Thaler and Mullainathan (2008) state: "The standard economic model of human behavior includes three unrealistic traits-unbounded rationality, unbounded willpower, and unbounded selfishness-all of which behavioral economics modifies." cited from The Concise Encyclopedia of Economics

(http://www.econlib.org/library/Enc/BehavioralEconomics.html).

${ }^{6}$ See Persky (1995) for the origin of the term.

${ }^{7}$ The work that lead to the formulation of the well-known discounting model exemplifies that generations of economists had struggled with the conceptualization of time preferences, being well aware of all the human motivations and other factors that might affect intertemporal decision-making, as is nicely documented in the review by Frederick, Loewenstein and O'Donoghue (2002).

${ }^{8}$ Behavioural economics does not necessarily discard the rationality assumption. Although some writers (e.g., Ariely, 2008) refute the idea that agents behave rationally, others would not abandon the concept of rationality, albeit defined in a more complex structure, in theories of human behaviour (e.g., Gintis, 2009). 
model of modern economics, which assumes fully informed forward-looking agents who rationally act on complete information to maximize their own utility, has evidently emphasised the role of selfinterest as propagated by Adam Smith's Wealth of Nations (1776 [1981]). ${ }^{9}$

Unease with the assumptions of the mainstream model has been expressed by economists themselves at various points during the development of the field. Such criticism led to the development of alternative models that often amended the standard framework in order to incorporate psychologically more reasonable assumptions. For example, John Maynard Keynes emphasized the role of animal spirits and criticized the idea that agents (are assumed to) fully understand the complex macroeconomic structures and are able to perfectly forecast equilibrium prices and quantities (Keynes, 1936). Similarly, key assumptions of expected utility theory (Bernoulli, 1954; von Neumann and Morgenstern, 1947) were challenged by economists (e.g., Allais, 1953). Some elements of such heterodox theories, including features that mark modern behavioural economic theories, were absorbed by the mainstream, which sometimes complicates a clear demarcation of behavioural economics from the mainstream model.

An important impetus for the development of behavioural economics as a field originated in the second half of the $20^{\text {th }}$ century from the influential criticism of scholars of related social sciences, most notably psychology and sociology, who challenged the neoclassical model by developing ideas about bounded rationality (Simon, 1955), biases and heuristics in decision-making (Tversky and Kahneman, 1974), prospect theory (Kahneman and Tversky, 1979), framing effects (Tversky and Kahnemann, 1981), and inconsistency in intertemporal choice (Ainslie, 1991). ${ }^{10}$ This arguably motivated a new generation of economists to accumulate more evidence on violations of standard theory. In the late 1980s and 1990s, Richard Thaler (together with various co-authors) featured such evidence in a column in the Journal of Economic Perspectives. In particular, this documented evidence on the existence of nonstandard preferences, such as violations of the exponential

\footnotetext{
${ }^{9}$ The mainstream model of modern economics is heavily influenced by the neoclassical framework which emerged in the late $19 \mathrm{~h}$ century and early $20^{\text {th }}$ century from the work of economists such as Thorstein Veblen. It culminated in rational choice theory (Robbins, 1932). There is some inconsistency about the usage of the term neoclassical. As is pointed out by Colander (2000), economists who shaped the "marginal revolution" (e.g., Menger, Jevons, Clark, Walras, and later Marshall) are sometimes called neoclassical economists. The work of these economists heavily rested on the use of mathematical methods and contributed to the mathematization of economics. This in turn also shaped some of the key assumptions that are still central to the modern mainstream model, such as a concept of rationality that is consistent with constrained optimization. Confusingly, the term neoclassical economics is also often used to "juxtapose modern mainstream economics with heterodox economics" (Colander, 2000, p. 132).

${ }^{10}$ Research on discounting in economics was deeply influenced by psychologists, in particular by George Ainslie's work on preference-reversals, impulsiveness and self-control (Ainslie, 1974; 1975) and Walter Mischel's work on delay of gratification in children (e.g., Mischel, Shoda and Rodriguez, 1989).
} 
discounting model (see e.g., Frederick, Loewenstein and O'Donoghue, 2002 for a review) or the assumption that all agents are selfish (see e.g., Fehr and Gächter, 2000a; 2000b). ${ }^{11}$

With a lag of a length that roughly coincides with time it takes to breed a new generation of Ph.D. students, economists started to develop theories that could account for the "new empirical facts" on the drivers of human motivation. ${ }^{12}$ A large class of these "behavioural models" allow for "nonstandard" preferences, in particular incorporating other-regarding preferences (Rabin, 1993; Levine, 1998; Fehr and Schmidt, 1999; Charness and Rabin, 2000; Dufwenberg and Kirchsteiger, 2004; Falk and Fischbacher, 2006; Segal and Sobel, 2007), non-expected utility (Quiggin, 1982; Schmeidler, 1989), loss aversion and reference-dependent utility (Kőszegi and Rabin, 2006), and nonexponential discounting (Laibson, 1997; O’Donoghue and Rabin, 1999; see Doyle, 2013 for a survey). ${ }^{13}$ Other classes of models deviate from the mainstream model by assuming that agents' beliefs are systematically inaccurate (e.g., due to errors in updating as in Rabin, 2002a) or by acknowledging that agents make systematic errors in their decision, due to focus and salience (e.g., Chetty, Looney and Kroft, 2009; Kőszegi and Szeidl, 2013) or limited attention (Botti and Iyengar, 2006; Wilson et al., 2013), the use of wrong heuristics or being influenced for example by framing effects (Caplin and Martin, forthcoming), the social environment and peers (e.g., Akerlof, 1980; Austen-Smith and Fryer, 2005). ${ }^{14}$ Various overview articles survey (parts of) these theoretical developments and empirical evidence from the lab (e.g., Rabin, 1998; Camerer, 2006) and the field (e.g., DellaVigna, 2009).

Several authors have asserted that behavioural economics can advance many fields of economics (see, e.g., Rabin, 2002b; Diamond and Vartiainen, 2007) and finance (Barberis and Thaler, 2003). ${ }^{15}$ It is easy to envision that much can be gained in labour economics by incorporating insights from behavioural theories, not least because psychological and social factors are particular important in labour markets (c.f., Kaufman, 1999). Social interaction, preferences for risk and uncertainty, and intertemporal decision making are central to the phenomena that labour economics seek to

\footnotetext{
${ }^{11}$ Some of these "anomalies", relating for example to social preferences and cooperation (Thaler 1988, Dawes and Thaler, 1988; Camerer and Thaler, 1995), loss aversion, risk preferences and time preferences (Kahnemann, Knetsch and Thaler, 1991; Loewenstein and Thaler, 1989; Rabin and Thaler, 2001; 2002), and inter-industry wage differential (Thaler, 1989) seem to be particularly relevant for labour economists.

${ }^{12}$ Some models were based on modifications of a few assumptions, while other approaches where more radical in nature. It is interesting to note, that even relaxing simplifying assumptions sparked off fierce debates about the adequacy of the new assumptions, even when they allowed for modeling important aspects of human motivation that had been previously deliberately disregarded that economists to trade off realism for parsimony.

${ }^{13}$ See Sobel (2005) for a review of models on non-selfish behavior and Starmer (2000) for a survey of models that depart from the expected-utility framework; and Frederick, Loewenstein and O'Donoghue (2002) for an overview of discounting models.

${ }^{14}$ DellaVigna (2009) categorizes these deviations from the standard model as nonstandard beliefs and nonstandard decision making.

${ }^{15}$ In fact, this has already happened as several concepts and ideas have arguably become mainstream.
} 
understand, such as the wage-effort relationship, wage determination, human capital accumulation, search behaviour, wage and career mobility, or intertemporal labour supply decisions. Beyond preferences, a wide range of other psychological factors such as personality traits and beliefs (e.g., locus of control) likely affect why, when, where, and how much we work. Although traditional behavioural economists ${ }^{16}$ would not consider research on the origin, determinants and economic consequences of heterogeneity in economic preferences and personality traits as a branch of behavioural economics, I consider this line of research to be a facet of the behavioural economics approach; for it complies with the definition that behavioural economics seeks to increase the explanatory and predictive power of economics by offering a more realistic psychologically plausible foundation (c.f., Camerer and Loewenstein, 2004; Angner and Loewenstein, 2012).

\section{The impact of behavioural economics on labour economics}

It is probably fair to say that the vast majority of labour economists were initially reluctant to incorporate insights from behavioural economics, such as the role of social preferences in labour relationships. The prevalent conservatism in the field came along with a critical attitude towards experimental methods, which were widely used in behavioural economics. This seems to have attenuated the impact of behavioural economics on labour economics at least until the mid-1990s. While scholars might disagree about the speed at which behavioural economics has affected labour economics, ${ }^{17}$ it is undeniable that behavioural economics has by now found its way into labour economic research. This is evident by the proliferation of studies that move away from the homo economicus assumption in order to explain labour market behaviour and outcomes. Various overviews have surveyed (parts of) this now fast growing behavioural labour economics literature (e.g., Berg, 2006; see also sections of DellaVigna, 2009, and references below). One could object that the sheer number of published studies in labour economics that use a behavioural economics approach is not a meaningful metric to judge the impact of behavioural economics on labour economics. Yet, it is irrefutable that behavioural economics has profoundly changed labour economics over the last decades. This is evident from at least three facts. First, numerous publications in the field of labour economics that build on or incorporate insights from behavioural economics are published in top journals, and many of these articles are widely cited (e.g., studies cited below). Some have even initiated a new strand of literature, such as the literature on gift-

\footnotetext{
${ }^{16}$ Traditional behavioural economists do not believe that preferences and personality traits are stable across context, and hence maintain that preferences parameters and personality traits have little predictive validity of behaviour across contexts. In their view behaviour is predominately driven by incentives and constraints.

${ }^{17}$ Kaufman (1999), for instance holds that labour economics lagged behind other fields in integrating insights from psychology.
} 
exchange in the labour market (Akerlof, 1982) or reference-dependence in labour supply (Camerer et al., 1997).

Second, there has been a growing emphasis on micro labour, which reflects the fact that behavioural economics first and foremost focuses on individual decision-making and human interaction. ${ }^{18}$ Evidently, the main aspects of human nature that have been integrated into behavioural economic theory, i.e. nonstandard preferences, nonstandard beliefs and nonstandard decision-making (see DellaVigna, 2009), determine decision-making and social interaction. Moreover, insights from personality psychology, which have been considered more recently by economists (see Borghans et al., 2008; Almlund et al., 2011) focus on individual differences, i.e. on the micro level. Naturally, behavioural economics had a relatively stronger impact on microeconomic analyses of labour market behaviour and outcomes. This is not to say that insights from psychology are not important for macro labour issues. On the contrary, small deviations from the predictions of the standard model at the micro level might lead to large aggregate effects. Keynes (1936) had already pointed this out in chapter 12 of The General Theory of Employment, Interest and Money by the example of a beauty contest; and experimental evidence from the "guess $2 / 3$ of the average"-game indicates that we cannot rely on common knowledge of rationality (see Nagel, 1995). This has important implications for outcomes at the macro level. Fehr and Tyran (2001), for example, provide experimental evidence that a modest degree of money illusion at the individual level can generate a substantial degree of nominal rigidity in the aggregate. ${ }^{19}$ Several prominent accounts acknowledge the importance of incorporating insights from behavioural economics into macroeconomic models (e.g., Akerlof and Shiller, 2009). I will assert below that such a route is also promising for macroeconomic models of the labour market.

Third, the emergence of behavioural economics led to a proliferation of experimental methods in labour economics, although arguably with some delay: Scholars in other fields (e.g., game theory) were much more receptive of experimental methods early on than labour economists, who often discarded evidence from laboratory experiments as irrelevant. Once accepted, however, the spread of experimental methods was probably catalysed by the long tradition of empirical work in labour economics, which arguably renders the field amenable for new empirical insights. A first wave of contributions in behavioural labour economics provided experimental evidence for the role of social preference in laboratory labour markets. Labour economists started to appreciate the fact that experimental methods make it possible to uncover the drivers and nature of human motivation, which are typically not easily observable in the field. They also gradually came to appreciate the

\footnotetext{
${ }^{18}$ Advances in microeconometrics undoubtedly also contributed to this development.

${ }^{19}$ Weber et al. (2009) provide neurophysiological evidence of the existence of money illusion at the level of the individual.
} 
advantages of laboratory experiments, such as the possibility of introducing truly exogenous variation in a controlled environment that allows precluding the influence of confounding factors. ${ }^{20}$ This also created spillover effects on traditional areas of labour market research, such as principalagent theory or bargaining (see Charness and Kuhn, 2011, for a review). The usefulness of controlled laboratory experiments for testing theory is particularly important because research in behavioural (labour) economics led to the arrival of new ideas and theories, creating a need for testing theory. ${ }^{21}$

Behavioural economics has profoundly changed labour economics in various areas (e.g., intertemporal labour supply, the wage-effort relationship, the role of fairness norms in wage determination) and stimulated new lines of research (e.g., on the psychology of incentives, social comparison, and peer effects). Since several accounts have already surveyed the most prominent strands of literature in (behavioural) labour economics - including fairness concerns (Gächter and Fehr, 2002) and wage rigidity (Bewley, 1999; 2007), the psychology of incentives (Kamenica, 2012; Fehr and Falk, 2002), or personality psychology and economics (Almlund et al., 2011) - I will not provide an exhaustive discussion of the literature but rather summarize what we have learned from behavioural labour economics research, document which new research questions arose, and sketch how the new research topics emerged. I will focus on a few lines of research to exemplify that there is no single answer to the question of why and when labour economists became interested in behavioural economics. The examples I have chosen reveal patterns of timing and proliferation. They also disclose that progress is fast in some areas but lagging behind in others. It will also become clear that progress was not always systematic. Motives for incorporating ideas from behavioural economics into labour market research are diverse. It seems that some work was merely inspired by the desire to float on the wave of success of behavioural economics. Key contributions, however, were often driven by the idea of employing the methods and insights from behavioural economics to find new answers to questions on which the field had gotten stuck. In some cases, this led to a new line of research, in which a research programme developed. Such research programmes hardly ever proceeded in a Popperian manner, but rather showed streaks of a Lakatosian approach.

I structure the discussion by first focusing on the role of nonstandard preferences or utility functions in section 3.1, recapitulating what we have learned with respect to social preferences and social comparison, loss aversion, and non-exponential discounting. In section 3.2, I turn to a strand of literature that investigates the prevalence and consequences of heterogeneity in preferences and personality. I then argue in section 3.3 that insights on nonstandard-beliefs, systematic biases and

\footnotetext{
${ }^{20}$ See Falk and Fehr (2003) for an account on the advantages of labour market experiments and Falk and Heckman (2009) for the virtues of laboratory experiments in general.

${ }^{21}$ Falk and Heckman (2009) point out why lab experiments are useful; Falk and Fehr (2003) elucidate the advantages of experimental methods for labour economics.
} 
the use of heuristics have not yet been introduced into models of the labour market in a systematic manner, and speculate that the integration of systematic biases in beliefs and decision-making into search models and macroeconomic models of wage and employment determination is a promising route for future progress in labour economics.

\subsection{Nonstandard Preferences}

\subsubsection{Social Comparison and Social Preferences}

\section{Social comparison}

Social comparison is a prerequisite for any model of fairness, reciprocity, altruism, or other types of interdependent preferences, because these theories model fairness judgments and resulting nonselfish behaviour based on a comparison of an individual's own outcomes relative to the outcomes of relevant others. Relative comparison is irrelevant in traditional economic models of individual greed. However, the view that individuals care only about their absolute consumption level and own utility has long been challenged in the social sciences (Festinger 1954, Olson et al., 1986). Economists have also argued recurrently that relative comparison affects utility and decision making (see Veblen, 1899; Duesenberry, 1949; Pollak (1976); Frank, 1985a; 1985b, 2005). Various empirical studies have argued that income comparisons affect life satisfaction (e.g., Clark and Oswald, 1996; Luttmer, 2005; see also Clark, Frijters and Shields, 2008, and Clark, Masclet and Villeval, 2010, for surveys). ${ }^{22}$

Fliessbach et al. (2007) and Dohmen et al. (2011b) provide neurophysiological evidence that higher relative rewards for equal task performance positively affect reward related brain areas. ${ }^{23}$ Relative comparison has far-reaching implications for labour markets as it affects labour supply (Neumark and Postlewaite, 1998), wage profiles (Frank and Hutchens, 1993) and effort provision (see e.g., Hamermesh, 1975; Cohn et al., 2014) and the design of optimal incentive systems (Bartling and von Siemens, 2010). Yet, the area that has been most widely studied in labour economics is that of social comparison at the workplace. Building on a long tradition of research in social psychology (see, e.g.,

\footnotetext{
${ }^{22}$ The literature on life satisfaction and happiness is particularly relevant for labour economists as labour market outcomes are an important determinant of life satisfaction (see e.g., Clark and Oswald, 1994; Frey and Stutzer, 2002), and because intrinsic rewards from work are an important component of personal happiness (Juster, 1991). Blanchflower and Oswald (2011) estimate that joblessness is associated with a large negative effect on happiness, which roughly compares to a permanent income loss of $100.000 \$$. Importantly, there is evidence that life satisfaction, happiness and positive affect influence earnings (De Neve and Oswald, 2012) and productivity (Oswald, Proto and Sgroi, forthcoming).

${ }^{23}$ In their experiments, pairs of subjects had to simultaneously perform a simple estimation task, while being scanned in two adjacent brain scanners. Monetary rewards were given for correct answers. Using functional magnetic resonance imaging ( $\mathrm{fMRI}$ ), they show that variation in the comparison subject's payment affects blood oxygenation level-dependent (BOLD) responses in the ventral striatum, the brain region that is involved in the prediction and registration of primary rewards such as food delivery as well as more abstract forms of rewards like money.
} 
Adams, 1965), various studies have assessed the consequences of wage schemes that violate the norm of equity (e.g. Abeler et al, 2010; Gächter and Thöni, 2010). The study by Card et al. (2012) among employees of the University of California provides evidence that the disclosure of information on peers' salaries causes a reduction of job satisfaction and an increase in turnover intentions among those earning below median salaries, while employees above the median are unaffected. Social comparison has been argued to be a source of pay compression (Stark and Hyll, 2011; Frank, 1984), and it likely affects performance evaluation distributions inside firms (see also Berger, Harbring and Sliwka, 2013).

Another strand of literature that is discussed in section 3.3 has assessed how behaviour in the workplace changes in the presence of others. Again, social comparison is an essential factor for such peer effects. Relative comparison is also related to the literature on reference points and loss aversion, which I discuss in section 3.1.2, as it can be a source of social reference points, such as fairness norms, effort norms, or professional norms (see Rebitzer and Taylor, 2011, and references therein). Social references points have been argued to affect a wide range of labour market outcome, including labour supply, effort provision, job satisfaction and the relation between (relative) income and happiness.

Of all deviations from the assumptions of the mainstream model, the implications of nonstandard preferences have probably received most attention in labour market research. Most of this line of research has focused on gift-exchange and the role of fairness norms and reciprocity (see Fehr, Goette and Zehnder, 2009, for a review). This line of research the has fundamentally changed the way labour economists think about the wage-effort relationship, nominal wage rigidity, the consequences of minimum wage laws and unemployment.

\section{Reciprocity and Fairness}

Akerlof (1982) formalized how fairness norms and reciprocity affect wages and effort provision. A subsequent important impetus was the fair-wage hypothesis proposed by Akerlof and Yellen (1990), which postulates that workers withdraw effort when their wage falls below the level they consider to constitute a fair wage. ${ }^{24}$ Such a fairness norm becomes a reference point. Rewards below this reference point are perceived by workers as a hostile act and outcomes above the reference point as a kind treatment. A prerequisite for fairness norms to affect work effort is reciprocity. Positive reciprocity is an in-kind favourable response to friendly actions while negative reciprocity entails punishment of hostile acts (Fehr and Gächter, 2000a). Hence it is not surprising that research on the

\footnotetext{
${ }^{24}$ There is evidence that unfair pay does not only trigger negative reactions towards the principal, but also evokes physiological responses. A recent study by Falk et al. (2013) documents that agents whose reward expectation are not met have a lower heart rate variability, which is an indicator of stress.
} 
role of reciprocity as a driving force of worker motivation became particularly influential. Psychologists and economists have shown that reciprocity is a key driver of human motivation by psychologists and economists in a host of controlled laboratory experiments (see Fehr and Schmidt, 2006; Bowles, 2008). Akerlof's work has sparked a large and influential literature of gift-exchange, which gained momentum with the development of an experimental game, the gift-exchange game (Fehr, Kirchsteiger and Riedl, 1993), that lends itself for testing gift-exchange theory in the lab. A host of subsequent studies adopted this framework and solidified the idea that workers reciprocate fair treatment of their employers by increased effort provision. The resulting positive wage-effort relation helps solving the principal-agent problems in settings of contractual incompleteness. Since effort is often unobservable or not third-party enforceable, reciprocity seems to be an important driver of labour market outcomes. ${ }^{25}$ Using the gift-exchange game, Fehr and Falk (1999) study a laboratory labour market with an oversupply of workers. They show that firms do not contract with workers offering to work for low when effort levels could not be enforced by a contract, but that such workers were not refused when workers could not adjust along the effort margin. This finding documents that employers fear low worker morale in response to low wages when effort levels are not enforceable. The gift-exchange game became the workhorse for studying the effect of labour market institutions in experimental labour markets and a range of outcomes (see Fehr and Falk, 2002), including wage setting behaviour of firms (e.g., Abeler et al., 2010) the formation of long-term employment relationships (e.g., Brown, Falk and Fehr, 2004), involuntary unemployment (Altmann et al., 2014), effects of minimum wage laws (Falk, Fehr and Zehnder, 2006), and effects of employment protection legislation (Falk, Huffman and McLeod, 2008).

In order to exemplify the propagation and impact of this strand of literature, I plot the development of citations (collected on google scholar) of Akerlof (1982), Fehr, Kirchsteiger and Riedl (1993) and Brown, Falk and Fehr (2004) in Figure 1. Annual citations of the paper by Akerlof (1982) were clearly increasing in the 1980s. But it is also evident that the literature gained new momentum with the development of the gift-exchange game by Fehr, Kirchsteiger and Riedl (1993) as is apparent by the steep increase in annual citations of Akerlof (1982) in the mid-1990s. This is at least partly the result of a proliferation of studies that rely on the gift-exchange game. Some of these studies are again widely cited as is documented by example of the Fehr and Falk (1999) paper. Akerlof's (1982) idea that effort provision depends on fairness norms and is affected by reciprocity is by now ingrained in labour economists' minds. It is widely accepted that fairness motives and reciprocity drive behaviour

\footnotetext{
${ }^{25}$ The positive wage-effort relation, induced by social preferences, also produces strategic reputational motives for non-reciprocal types in repeated interactions between worker and firm, thus reinforcing the positive relation between wages and effort (Gächter and Falk, 2002).
} 
and aggregate outcomes such as wage rigidity and involuntary unemployment (e.g., Altmann et al, 2014) in laboratory labour markets.

\section{INSERT FIGURE 1 ABOUT HERE}

However, there is a debate whether these motives also affect outcomes in actual field settings (Levitt and List, 2007) ${ }^{26}$. Bellemare and Shearer (2009) document that providing an unexpected bonus that is unrelated to past productivity in a field experiment at a tree-planting firm has a significant and positive effect on productivity; but Gneezy and List (2006) argue, for example, that an unexpected salary raise has only a short-lived positive effect. However, Kube et al. (2012) demonstrate that nonmonetary gifts have a much stronger impact on worker effort provision than monetary gifts. In general, the effects of wage increases is somewhat contested and effects might depend on context. ${ }^{27}$

Evidence for the importance of reciprocity, fairness and social preferences in actual labour markets is documented beyond the gift-exchange context. Bandiera, Barankay and Rasul (2005) provide fieldexperimental evidence that workers moderate effort provision when it imposes negative externalities on witnessing co-workers. Dohmen et al. (2009) provide survey evidence of a positive correlation between working overtime and positive reciprocity. Ockenfels, Sliwka and Werner (2014) analyse personnel data from a large international firm and find that managers who receive a bonus below a salient reference point reduce performance subsequently. They conjecture that this reference point constitutes the norm for fair treatment. It is important to note that there is ample evidence that employers are aware of such fairness motives. A survey among managers conducted by Bewley (1999), for example, reveals that managers refrain from wage decreases because they fear resentment of workers who interpret nominal pay cuts as an insult or hostile act (see also Agell and Lundborg, 2003). The fear of retaliation in response to unfair treatment hence seems to be an important driver of downward nominal wage rigidity (see Bewley, 2007, and references therein).

In fact, negative reciprocity potentially has even greater consequences for labour market outcomes than positive reciprocity. In their fascinating case study, Krueger and Mas (2004) provide evidence that a labour strife at a U.S. tire production site coincided with the production of substantially lowerquality tires, which arguably resulted from the reduced effort and care of workers during the strife.

\footnotetext{
${ }^{26}$ Some of the arguments that are raised in this debate do not stand up to critical scrutiny. For example, there is evidence that students are not more prosocial than non-students (Cappelen et al., 2014; Henrich, Heine and Norenzayan, 2010) and that students who self-select into experiments are not more prosocial than nonstudents (Falk, Maier and Zehnder, 2013).

${ }^{27}$ Cohn et al. (2014) conducted a field experiment in which wages are increased. The effort response depends on workers' fairness perceptions at baseline: Those who felt poorly paid before the wage raise react strongly to the wage increase by raising effort, while workers who perceived the baseline wage as fair already to not work harder in response to the wage increase. Kube et al. (2013) found wage increases have little effect on performance, but that wage cuts have a detrimental and persistent impact on productivity.
} 
The importance of harmful reciprocations in labour relationships is also documented by Mas (2006), Mas (2008) and Kube et al. (2013). ${ }^{28}$ Montizaan et al. (2012) identify negative reciprocity as the main driver for workers' reaction to unfair treatment, showing that the reduction in work motivation in response to a pension reform that is perceived as unfair depends on their disposition towards negative reciprocity. ${ }^{29}$

In summary, the previous discussion demonstrates that other-regarding preferences play an important role in the labour market, a fact that is by now well-accepted among labour economists. However, this is not to say that the selfishness assumption is irrelevant. In truth, there is pervasive evidence of pronounced heterogeneity in types (see, e.g., Fischbacher, Gächter and Fehr, 2001) ranging from completely selfish types to altruistic types. This spectrum is broad and it includes inter alia conditional co-operative types and unconditional cooperative types. The prevailing equilibrium (or labour market outcome) is not merely determined by the fractions of the various types, but also by the institutional setting in which heterogeneous types interact. ${ }^{30}$ Evidently, there are many situations in which selfishness drives decision-making of labour market participants. The key to predicting outcomes in labour markets is thus an understanding of the factors, conditions and institutional arrangements under which other-regarding preferences or selfishness govern behaviour. As a result, there is probably no future research needed to show that individuals exhibit social preferences, but rather there is a need for assessing when and how social preferences govern behaviour in long-term labour relationships.

\subsubsection{Loss aversion and reference-dependent utility}

\footnotetext{
${ }^{28}$ Mas (2006) documents that police performance deteriorated in response to adverse outcomes in final offer arbitrations for police unions in New Jersey; Mas (2008), demonstrates that quarrels between a union and Caterpillar coincided with substantially reduced quality of construction equipment produced by Caterpillar in that period; Kube et al. (2013) found that wage cuts have a detrimental and persistent impact on productivity of student workers in a data entry job, while an equivalent wage increase has no effect.

${ }^{29}$ They use a regression discontinuity design in order to study how a pension reform that curtailed pension rights of Dutch public sector workers who were born after a particular date affects work morale. Employees affected by the reform report a significantly lower job motivation than employees who are slightly older and therefore unaffected by the reform. Showing that severity of the reduction in work motivation depends on the strength of negatively reciprocal inclinations, they establish the link between the disposition towards negative reciprocity and the severity of the reduction in response to perceived unfair treatment.

${ }^{30}$ For example, evidence from repeated public good games demonstrates that selfish individual free-ride drive down contributions to the public good in absence of punishment institutions. However, when there is an opportunity for costly punishment, high contribution levels can be sustained when there are types who are willing to punish free-riders (see Fehr and Gächter, 2000b; Gächter, Renner and Sefton, 2008). Free-riders are disciplined once punishment is a credible threat. Beliefs about the type of others play a crucial role in public good games (Fischbacher and Gächter, 2010).
} 
Reference-points are a core element of prospect theory developed by Kahneman and Tversky, which incorporates the idea that individuals evaluate lotteries relative to a reference point, and do not necessary evaluate it at their final wealth position. Loss aversion arises when individuals prefer avoiding outcomes below the reference point to acquiring same-sized outcomes above the reference point. ${ }^{31}$ The idea that reference points affect the evaluation of outcomes is central to behavioural economics, and has affected various sub-fields of labour economics, particularly the literature on labour supply (e.g., Dunn, 1996).

Particularly prominent is the line of research that studies the response of workers to transitory wage changes (see also Charness and Kuhn, 2011, section 3.1.5). Camerer et al. (1997) found a negative correlation between wages and hours supplied by cabdrivers in New York city, which is consistent with income-targeting (a strong form of reference-dependence), but not with the neoclassical intertemporal labour supply model, which posits a positive correlation between transitory wage increases and hours of work supplied. Their interpretation of the data sparked a vivid debate, which reveals the caution and conservativeness of labour economists. Labour economists were critical about the conclusions of Camerer et al. (1997) and pointed out shortcomings of their analysis (e.g., Barmby, 2004). Others were inspired to provide evidence in favour of the mainstream model (e.g., Oettinger, 1999). Farber (2005) used similar data on New York cabdrivers to test another important implication of the labour supply model, namely whether the hazard rate of stopping work increases, and concluded that his finding of an increasing hazard rate during the day is not consistent with income-targeting but with the implications of the standard intertemporal labour supply model. The dispute triggered field experiments, in which the transitory wage changes were exogenously imposed by the experimenter. Fehr and Goette (2007), who ran a field experiment among bicycle messengers in Zürich, indicate the importance of reference points, by showing that the daily effort choices of individuals who reveal loss aversion in choice-experiments are more prone to be influenced by income targets. These findings somewhat reconciled previous conflicting evidence and inspired the development of theory (e.g., Kőszegi and Rabin, 2006), its application to the labour market for NYC cabdrivers (Crawford and Meng, 2011), and the development of experimental tests of the theory (Abeler et al, 2011).

The fervent discussions between those who challenged the mainstream intertemporal labour supply model and those who defended it led to a number of important insights for the labour supply literature (c.f. Goette, Huffman and Fehr, 2004): (1) Participation increases in response to transitory wage increases (e.g., Oettinger, 1999; Barmby and Dolton, 2009). Labour supply at the extensive

\footnotetext{
${ }^{31}$ See Kahneman, Knetsch and Thaler $(1990,1991)$ for experimental evidence on the prevalence of loss aversion. Note that List (2003) argues that competitive forces and self-selection can tame or even eliminate the relevance of loss aversion in market settings.
} 
margin is therefore consistent with the predictions of the standard model of intertemporal labour supply. (2) At the intensive margin, however, there is evidence that reference-dependence affects labour supply. Income targets seem to drive the behaviour of individuals to work less hard in response to unexpected transitory wage increases (Camerer et al., 1997; Chou, 2002, Fehr and Goette, 2007; Farber, 2008; Crawford and Meng, 2011; Abeler et al., 2011). (3) Yet, there is important heterogeneity in worker types (Doran, 2009). (4) There are labour supply models with reference-dependent preferences that yield better predictions than the neoclassical intertemporal labour supply model. Scholars had initially questioned the usefulness of the incorporation of loss aversion in models to predict labour supply as the data implied that reference points (income targets) varied vastly from day to day and are seemingly difficult to predict (e.g., Farber, 2005). However, building on the theory by Kőszegi and Rabin (2006), which was developed to predict relevant reference-points, Crawford and Meng (2011) show for the case of NYC cabdrivers that a model with expectation-based endogenous income and hours targets explains the data well. Abeler et. al (2011) provide experimental evidence that supports the assumption of expectation-based reference points in Kőszegi and Rabin (2006).

\subsubsection{Deviations from the exponential discounting model}

Research in behavioural economics provided evidence that refutes the exponential discounting model (see Frederick, Loewenstein and O'Donoghue, 2002). In particular, time-inconsistent intertemporal choice behaviour has been argued to be a pervasive phenomenon (Ainslie, 1975; Frederick, Loewenstein and O'Donoghue, 2002; Thaler and Benartzi, 2004). This triggered the interest in developing non-exponential discounting models, such as hyperbolic discounting models (see Doyle, 2013, for a survey). Laibson (1997) proposed a particular parsimonious and mathematically tractable version, the quasi-hyperbolic discounting, which predicts that individuals engage in activities that generate short-term pleasure but even higher long-term costs and delay investments that are profitable in the long-run. The framework therefore lends itself to the study of self-control problems (O'Donoghue and Rabin, 1999; 2001). Although intertemporal choices are pervasive in the labour market (e.g., human capital investments, deferred compensation, intertemporal effort provision), models that deviate from the exponential discounting assumption have not been employed on a large scale to study decision-making in labour markets. In general, nonstandard discounting has only had a modest effect on labour economics, which also occurred relatively late. DellaVigna and Paserman (2005) is probably the first influential study that systematically applied hyperbolic discounting to decision-making in the labour market. They investigate theoretically how impatience and hyperbolic discounting affect job search outcomes, and 
then provide empirical evidence for the existence of time-inconsistent agents who end up investing less effort in job search than they retrospectively wish to have done. ${ }^{32}$ This line of research is continued by Paserman (2008) and Cockx, Ghirelli and van der Linden (2014).

Figure 2 presents the number of annual citations to the theory by Laibson (1997), the survey article by Frederick, Loewenstein and O'Donoghue (2002), and the application to labour markets by DellaVigna and Paserman (2005).

\section{INSERT FIGURE 2 ABOUT HERE}

A comparison to Figure 1, which documents how social preferences had an impact on labour economics, reveals that deviations from the exponential discounting assumption had a rather modest impact on labour economics, despite its profound influence on the economics profession at large. While the number of citations of the papers by Laibson (1997) and by Frederick, Loewenstein and O'Donoghue (2002) is steadily rising, which indicates applying the ideas of non-exponential discounting gained momentum in the economics profession at large, labour economists were quite late in incorporating non-exponential discounting in their models. In addition, such lines of research of which DellaVigna and Paserman (2005) is a prominent example, evolved rather slowly in comparison applications in other areas of economics.

One reason for the reluctance of labour economists to incorporate non-exponential discounting in their models might be the conflicting evidence on discounting behaviour and the accompanying ongoing debate about the adequacy of alternative discounting models (e.g., Dohmen et al. 2012a; Augenblick, Niederle and Sprenger, 2013). Resulting measurement problems seem abundant, and measurement error in discounting parameters is prone to be large. This is likely to contribute to the fact that correlations between elicited discount rates and field behaviour are typically small (see also Chabris et al, 2008). Another reason is that different discounting models often generate ambiguous predictions and are therefore difficult to test empirically. Nevertheless, there seems to be promising research in labour economics ahead that incorporates insights from behavioural economics on nonexponential discounting. Examples include the analysis of schooling and training choices or retirement saving choices.

\footnotetext{
${ }^{32}$ They set up a search model with endogenous search effort and a reservation wage decision and derive theoretically that exponential discounting generates a positive correlation between the level of the discount rate and the hazard rate of leaving unemployment, while this correlation is negative if individuals have hyperbolic time preferences. They then estimate this correlation using behavioural outcomes (such as behaviour during the interview, having a bank account or life insurance, use of contraceptives, alcohol consumption and smoking behaviour) that are related to patience as proxies for time preference.
} 


\subsection{Individual differences: Preference Heterogeneity and Personality}

\subsubsection{Heterogeneity in preferences}

Research in behavioural economics on the nature of preferences clearly increased awareness about the importance of preference heterogeneity, not least because experimental elicitation methods that were developed to measure social preferences, risk preferences and time preferences in the lab revealed considerable differences in preferences across individuals. ${ }^{33}$ This generated interest in studying the distribution of preferences in the broad population. One strand of literature used experimental methods applied to subject pools drawn from the general population to study risk and time preferences (e.g., Harrison, Lau, Rutström, 2007; Harrison, Lau, Williams, 2002; Dohmen et al., 2010) and social preferences (Bellemare and Kröger, 2007). Due to the costs involved in experimental preference elicitation, these samples were small. Given the diverse background of participants in these field studies and the rather limited information on job characteristics, firm characteristics, career dynamics and other relevant labour market characteristics, these data sets typically did not lend themselves to studying how preference heterogeneity maps into heterogeneity in labour market behaviour and outcomes. ${ }^{34}$ This line of research was clearly facilitated when experimentallyvalidated survey measures of preferences became available in large-scale panel studies (see e.g., Dohmen et al., 2011a). ${ }^{35}$ A growing literature investigates, for example, the role of risk preferences for educational investments (see Hartog and Diaz-Serrano, 2013, for a comprehensive survey), occupational choice (e.g., DeLeire and Levy, 2004; Bonin et al., 2007) ${ }^{36}$ and the decision to become self-employed (e.g., Caliendo et al., 2009; Cramer et al., 2002; Ekelund et al., 2005).

\section{Preference heterogeneity and sorting into incentive systems}

An intriguing line of research in labour economics investigates how preference heterogeneity and incentive contracts interact. These studies have provided experimental evidence for a causal impact

\footnotetext{
${ }^{33}$ Güth, Schmittberger and Schwarze (1982) first studied social preferences in the context of the ultimatum game. Modified versions include the game studied in Kahneman, Knetsch and Thaler (1986), which has been simplified further in later research and is now known as the dictator game (see Engel, 2011). The gift-exchange game developed by Fehr, Kirchsteiger and Riedl (1993), the investment game developed Berg, Dickhaut, McCabe, 1995) and modifications of it (Abbink, Irlenbusch, Renner, 2000) are now also widely used to assess various facets of other-regarding preferences. Risk preferences are typically elicited in lottery choice experiments (e.g., Holt and Laury, 2002), while time preferences are commonly studied in the lab by using intertemporal choices involving monetary rewards (see Frederick, Loewenstein, and O'Dohoghue, 2002). ${ }^{34}$ Tinbergen (1956) was already studied how heterogenous workers are allocated to heterogeneous jobs. ${ }^{35}$ Recently, Falk et al. (2014) developed a survey preference module that has been administered in 76 countries.

${ }^{36}$ The idea that agents sort into occupations that differ in terms of riskiness is linked to the literature that documents wage premiums for riskier jobs (see, e.g, and Hartog et al., 2001).
} 
of key economic preferences on the choice between alternative payment incentives. ${ }^{37}$ Since any attribute that differentially affects agents' utility from working under alternative contractual arrangements is expected to determine their decision to sort into a particular incentive scheme (see e.g., Lazear, 2000, for the role of productivity sorting), sorting patterns are multidimensional (see e.g., Cadsby et al., 2007; Dohmen and Falk, 2011; Eriksson et al., 2009; Larkin and Leider, 2012; Niederle and Vesterlund, 2007). This mechanism has far reaching implications for a whole range of labour market outcomes, including occupational sorting, the gender composition in occupations and firms, the gender wage gap. Self-selection into incentive schemes affects the composition of the workforce and hence an organization's culture. An organization's success is not solely determined by workers' ability and task-specific skills, but also by the way that workers approach problems, deal with clients and complete tasks, which depends in important ways on their preferences, attitudes and personality. For example, there are jobs for which it is important to prevent workers from engaging in excessive risk taking (e.g., safety officers or engineers of nuclear power plants), while for other tasks (e.g., in research and development) daringness, i.e. willingness to take risks is preferable. Moreover, in the presence of worker self-selection into incentive schemes, changes in incentive systems and human resource practices take full effect only when the composition of worker types has changed. The duration of the process of re-sorting depends on a various factors including labour market institutions and job requirements. Importantly, changes in incentives trigger incumbent's resistance (Dohmen and Falk, 2010) as they create discrepancies in actual and preferred incentives. A particular interesting question in behavioural labour economics is whether such discrepancies induce work stress, which would fundamentally jeopardize workers' mental and physiological health and well-being.

\subsubsection{Personality traits}

Individuals do not only differ with respect to preferences, but also with respect to personality. In fact, psychologists would probably be inclined to describe individual differences in terms of personality. There is no unanimous definition of personality in personality psychology, the branch of psychology

\footnotetext{
${ }^{37}$ A set of studies has highlighted that incentive contracts induce sorting in dimensions beyond productivity. Laboratory experiments with real-effort tasks find that risk averse participants are less likely to sort into variable payment schemes when the alternative contract is a fixed wage (Cadsby et al., 2007; Dohmen and Falk, 2011), and prefer piece rate contracts to tournaments with a larger variance in expected earnings (Eriksson et al., 2009). Cable and Judge (1994) document a correlation between choice of contingent pay schemes and risk attitudes using survey information of students. Bellemare and Shearer (2010) provide evidence that Canadian tree planters who work on piece rate contracts are less risk averse than the general Canadian population. Niederle and Vesterlund (2007) show that gender differences in competitiveness affect the choice between tournaments and piece rates, and Larkin and Leider (2012) demonstrate that overconfident workers feel attracted to more ambitious pay-for-performance schemes.
} 
that studies human nature and individual differences in cognition, emotions and patterns of behaviour. Key components of personality are personality traits, which Roberts (2009, p. 140) defines as "the relatively enduring patterns of thoughts, feelings, and behaviors that reflect the tendency to respond in certain ways under certain circumstances". Psychology has a long tradition of measuring personality traits (see Borghans et al., 2008). Various models emerged that propose a taxonomy of traits, which is arrived at through factor analysis of subjectively assessed behaviours and attributes. This line of research can be traced to the work of Allport and Odbert (1936), who hypothesized that individual differences are encoded in language. The most prominent one - yet not uncontested one (Funder, 2001) - is the Five Factor Model, which posits that all personality traits are facets of one of five domains (see, e.g., Costa and McCrae 1992a). Within these domains, which are "big" in the sense that they each capture lots of traits, there exists a hierarchical organization of traits with sub-facets (that are highly but not perfectly correlated) and more narrowly defined traits at lower levels. ${ }^{38}$ The five factors at the highest level of this hierarchical organization, a.k.a. Big Five, are commonly labelled as openness to experience, conscientiousness, agreeableness, extroversion, and neuroticism. ${ }^{39}$

Several studies in psychology have shown that personality traits affect life outcomes (e.g., Roberts et al., 2007; Moffit et al., 2011), that economists also care about. In addition, some studies in labour economics have assessed the impact of Big Five traits on wages (Mueller and Plug, 2006; Heineck and Anger, 2010) and the effect of locus of control on search behaviour (McGee and McGee, 2011; Caliendo, Cobb-Clark and Uhlendorf, 2014) and the decision to obtain higher education (Piatek and Pinger, 2010). As a result, there is much reason to believe that an integration of the different measures and concepts used by economists and personality psychologists is promising. If there was a perfect analogy between the measures of personality psychology and preference parameters of economics, many empirical findings from psychology could be immediately mapped into an economic framework. If on the other hand there was little congruence between the drivers of human behaviour that were identified disjointedly in the two disciplines, there is much to gain by integrating personality into economic decision making. Becker et al. (2012) appraise the relationship between economic preference measures and psychological personality measures and conclude that the correlations between economic and psychological measures are small and that the two measurement systems are complements rather than substitutes in explaining important life outcomes, including educational attainment, earnings, unemployment, and life satisfaction.

\footnotetext{
${ }^{38}$ The Revised NEO Personality Inventory (NEO-PI-R) developed by Costa and McCrae (1992b), for example, identifies 6 sub-facets for each of the five factors.

${ }^{39} \mathrm{~A}$ prominent alternative trait based taxonomy of personality is the HEXACO model (see Ashton et al., 2004) which posits six factors. One domain, the "Honesty-Humility" domain captures predominately facets of fairness and other-regarding preferences.
} 
The intuition that personality traits affect success in many aspects of life had also inspired research on the returns to personality in the labour market (e.g., Jencks, 1979; Filer; 1981). Yet, this line of research was not followed up on large scale until about two decades later (see Bowles, Gintis, and Osborne, 2001a). It gained momentum again at the beginning of the $21^{\text {st }}$ century when labour economists acknowledged that standard human capital measures fall short of explaining the heterogeneity of earnings while pondering on empirical evidence that family background and other personal characteristics affect labour market success (see Bowles, Gintis and Osborne, 2001b). ${ }^{40}$ Empirical research on social mobility had revealed that inheritance of wealth and cognition cannot explain the intergenerational correlation in earnings (see, e.g., chapters in Bowles, Gintis and Osborne-Groves, 2005), while at the same time there is evidence for intergenerational transmission of personality traits (e.g., Loehlin, Horn and Willerman, 1981) and economic preferences (Dohmen et al., 2012b). Apparently, parents play a major role in the formation of these characteristics that are valued in the labour market (see Cunha et al., 2006 for a survey).

In recent years, research on the role of personality in determining labour market outcomes has become one of the most vibrant fields in contemporary labour economics. ${ }^{41} \mathrm{~A}$ major reason for the systematic progress in this area is probably the existence of research agendas that share elements of Lakatosian research programmes. ${ }^{42}$ The research program of James Heckman and co-authors, which aims to shed light on the sources of inequality, is a reflection of such a systematic approach. It can be traced to the early literature on earnings inequality and racial discrimination in U.S. labour markets. When it became evident after decades of research and the appraisal of various explanations that the black-white earnings differential observed after the civil rights policy of the 1960s (Donohue and Heckman, 1991) was largely explained by differences in skills, educational achievement and family background (Neal and Johnson, 1996), the quest for the sources of the black-white skill gap began. ${ }^{43}$ Different influences that might potentially lead to lower educational achievement of disadvantaged groups were assessed empirically, e.g., credit constraints (Carneiro and Heckman, 2003). But these aspects could not explain why children from disadvantaged family background tended to end up with

\footnotetext{
${ }^{40}$ For example, physical characteristics such as beauty (Hamermesh and Biddle, 1994) and height (Persico, Postlewaite and Silverman, 2004; Case and Paxson, 2008; Lindqvist, 2012) have been shown to affect earnings and labour market outcomes.

${ }^{41}$ Empirical work in this area was certainly catalysed when measures of personality became available in large data sets. The German Socio-Economic Panel study, for example, contains measures of Big Five traits since 2005 and measures locus of controls since 1994.

${ }^{42}$ This is not to say that labor economists in general are Lakatosian research programmers. In fact, progress is often fragmented rather than systematic and recurrently evolves ad hoc, for example when new data becomes available.

${ }^{43}$ The idea voiced by Herrnstein and Murray (1994) that ethnic differences in IQ exist that are genetically determined and that cannot be changed by policy interventions and environmental factors was heavily criticized and disproven. Hansen, Heckman and Mullen (2004), for example, show that AFQT scores, which Herrnstein and Murray interpreted as a measure of IQ, are malleable and are affected by schooling.
} 
low levels of achievement and poor labour market outcomes. This aroused the interest in appraising the impact of factors different from financial constraints or cognitive ability, such as economic preferences and psychological factors like motivation, perseverance or conscientiousness. Partly due to lack of data, a first wave of studies did not identify what personal attributes and traits exactly determine success in life, but rather gauged the importance of these characteristics by subsuming them in one factor that is conceptualized as being distinct from a factor of cognitive skills as captured by standardized tests or observable measures of human capital (e.g., Heckman and Rubinstein, 2001). ${ }^{44}$ This factor was termed noncognitive skills, in analogy to cognitive skills that are rewarded in the labour market. ${ }^{45}$

This analogy shaped progress as it suggests the idea that individuals can invest in such skills, just like human capital theory considers optimal investment in productive skills, and led to the development of models of skill formation that are characterized by the interplay of traits and investment such as schooling, but also learning-by-doing or by imitation as in Cunha and Heckman $(2007,2009) .{ }^{46}$ Yet, the "skill analogy" is not perfect. It might even mislead us to think that productivity is changing monotonically in a particular trait, and it certainly obscures the fact that traits can be valued quite differently in different jobs and contexts. This clearly complicates estimation of returns to personality traits as in Mueller and Plug (2006) or Heineck and Anger (2010), particularly in the presence of sorting into jobs and occupation based on such traits. Despite the tremendous progress that has been made on answering key questions relating to the relationship between various personality traits, their relationship with economic preferences, their stability and malleability over the life course (see Almlund et al, 2011), key challenges remain.

The biggest challenge ahead in labour economics is to identify which personality traits or systems of beliefs are important for which outcomes and why. As stated above, much of the empirical work cited above simply adds one additional factor that aggregates influences other than cognitive ability as an explanatory variable to an empirical model of a particular labour market outcome. Yet, it is intuitive that various traits and preferences matter for a particular labour market outcome, and without theory or solid empirical evidence we cannot readily establish that all these elements that matter can be subsumed in one factor, nor can we easily determine what elements should constitute such a factor. The choice of elements to identify this (latent) factor in empirical work has often been rather ad hoc and driven by pragmatism. Rather than being guided by theory, empirical work has

\footnotetext{
${ }^{44}$ The role of psychological factors beyond IQ or cognitive ability was also acknowledged by Hartog (2001) who reviewed evidence and theoretical approaches towards understanding the formation and utilization of these skills in the labour market.

${ }^{45}$ See, e.g., Heckman, Stixrud and Urzua (2006).

${ }^{46}$ Cunha, Heckman and Schennach (2010) estimate the technology of skill formation.
} 
been directed by data availability. ${ }^{47}$ This has created at least two problems: First, it is difficult to appraise differences in estimated effects across studies that use different traits to identify the impact of a "noncognitive skill" factor. Second, and potentially more serious is the fact that the entire approach of imposing a certain factor structure hides some of the interesting underlying mechanisms that generate the relation between personality and outcomes.

Establishing which facets of personality drive labour markets outcome through what channels is clearly facilitated by the development of models that incorporate personality traits in an economic framework (c.f. Borghans et al, 2008). The conceptualization of personality traits within such a framework will also deliver important insights for measurement, in particular on the dimensions along which measurement has to be standardized. Moreover, such theoretical insights will provide guidance concerning the personality traits to be measured in data sets used by labour economists. Economists have only recently started this process of model building to enrich economic theory (see Almlund et al, 2011). For the reasons mentioned above this research area is one of the most promising for the years to come.

\subsection{Nonstandard beliefs and nonstandard decision-making}

\section{Nonstandard decision-making}

Compared to work that introduces nonstandard preferences or personality into the analysis of labour markets, only a limited amount of work in labour economics has considered what DellaVigna (2009) classifies as nonstandard decision-making, despite the fact that gains from taking framing effects, menu effects, or narrow bracketing into account are potentially large, in particularly for studying individual schooling and training choices, savings and retirement decisions or job search behaviour. Evidence suggests, for example, that training decisions can be influenced by setting a default (Borghans and Golsteyn, 2014), indicating that individuals can be "nudged" to participate in particular training programs. In a related strand of literature it has been shown that retirement savings can be affected by the choice of default (Choi, Laibson and Madrian, 2004) or the design of the menu of investment options that individuals can chose from (Choi, Laibson and Madrian, 2009). Hence, there is probably scope for policies aimed at improving educational choices and retirement savings that take insights from psychology about biases in decision-making into account (see Thaler and Sunstein, 2008). The fact that the UK government installed "The Behavioural Insights Team" is a reflection of the awareness of such a potential among policy makers. It will be exciting to scrutinize

\footnotetext{
${ }^{47}$ Different data sets contain different measures (e.g., the NLSY contains measures of self-esteem and locus of control, while the SOEP contains Big Five traits and locus of control).
} 
the effects of their interventions that are intended to accelerate the transition from unemployment to work.

An area that has already attracted the attention of economists quite some time ago relates to the influence of the social environment on decision-making. ${ }^{48}$ The phenomenon that the presence of others can change individual behaviour and performance is known as the 'social facilitation' paradigm in social psychology (see Guerin, 1993, for an extensive account of theoretical and empirical social facilitation research). A small set of studies in the economics literature addresses the role of social influences on behaviour (see, e.g., Akerlof, 1980, 1997; Bernheim, 1994; Becker and Murphy, 2000; Austen-Smith and Fryer, 2005). Some studies, which provide evidence that social forces affect behaviour (e.g., Garicano et al., 2005; Dohmen, 2008a) are relevant for labour economics. ${ }^{49}$ Biased decision-making induced by social pressure or a preference for conformity has, for example, been argued to affect the principal-agent relationship (e.g., Prendergast, 1993).

A larger strand of literature has analysed whether peer effects exist at work. While it is difficult to identify peer effects (Angrist, forthcoming), there is some convincing evidence of productivity spillovers at the workplace. Mas and Moretti (2009) find that effort of cashiers at a supermarket is positively related to the productivity of co-workers within the range of vision. Falk and Ichino (2006) present evidence from a randomized control trial indicating that performance in an envelope-stuffing task is affected by the presence of a co-worker. De Grip and Sauermann (2012) analyse a fieldexperiment in which the provision of training was randomized at a large call-centre, and find evidence for productivity spillovers of trained workers to untrained team members. ${ }^{50}$

\section{Nonstandard beliefs}

Various insights from psychology are in conflict with the assumption that agents form rational beliefs about states of the world taking into account all relevant information and update these beliefs in a Bayesian manner. DellaVigna (2009) classifies deviations from this assumption as nonstandard beliefs. These kinds of deviations comprise phenomena such as overconfidence or non-Bayesian learning, which are expected to play a role in situations in which initial uncertainty about a key

\footnotetext{
${ }^{48}$ Analyzing the impact of the social environment on behaviour has a long tradition in social psyhology (e.g., Triplett, 1898), and received much consideration from sociologists (e.g., Coleman, 1990).

${ }^{49}$ See also Parsons et al. (2011) for evidence that agents are aware that others are affected by social forces and therefore adjust behaviour.

${ }^{50}$ By and large, the peer effects literature in labour economics emphasises performance increases in the presence of others, in harmony with the 'social support hypothesis' of social psychology, which holds that performance is boosted in a friendly environment. In contrast, the presence of (even friendly) others can also impair performance according to the 'social pressure hypothesis'. A recent strand of literature in economics has analysed the prevalence of performance decrements under pressure (Ariely et al., 2009; Dohmen, 2008b) and found - akin to the choking literature in psychology (see e.g., Beilock and Carr, 2001) - that context, task attributes and degree of professionalism matter.
} 
parameter for optimal decision-making diminishes as signals about the true value of the relevant parameter accumulate over time. As these features characterise a variety of decision environments in labour economics (e.g., investment in human capital or job search) developing labour market models with nonstandard beliefs seem to be a very promising route. Yet, models of nonstandard beliefs have so far only been sporadically applied in labour economics. A set of studies assesses the implications of agents being overconfident or having an overly positive self-image for the principalagent relationship. Santos-Pinto (2008), for example, investigates theoretically how agents' biased beliefs about their ability affect effort provision and optimal incentives in different information environments. In a similar set-up, Santos-Pinto (2010) studies effort provision in tournaments, and Larkin and Leider (2012) provide empirical evidence on the effect of overconfidence on performance in and selection into tournaments. Other studies have applied the concept to human capital investments (Santos-Pinto, 2012).

Applying nonstandard beliefs to job search models seems to be a particularly promising area of research. Spinnewijn (forthcoming) develops a model in which agents have biased beliefs regarding their job finding probability and shows that overly optimistic workers search too little and deplete their resources too fast, which has immediate consequences for unemployment duration and implications for the design of unemployment insurance. Falk, Huffman and Sunde (2006) provide experimental evidence that individuals who are uncertain about their job finding rate do not revise their subjective probability of finding a job sufficiently (i.e. less than predicted by Bayes' rule) based on search outcomes. As a result, individuals who start with an optimistic prior on their job finding rate search too little while those with a pessimistic prior end up searching too much. ${ }^{51}$

\section{Impact on EALE: evidence from conferences and the association's journal Labour Economics}

The developments in the literature at large are also visible within the EALE network, where behavioural economics has certainly contributed to (1) a shift in focus from macro labour issues (such as unemployment) to individual decision making within the field of labour economics, (2) an increase in the use of experimental methods and (3) a recent focus on personality traits and preferences. An inspection of all EALE conference programmes from the founding event in Turin in 1988 to anniversary conference in Turin in 2013 reveals this clear shift in topics addressed by members of EALE. Macro-labour topics such as macroeconomic models of unemployment, wage structure, wage inflation, working hours, bargaining and unions, social security and other labour market institutions

\footnotetext{
${ }^{51}$ A related literature in economics on base-rate neglect (see Dohmen et al., 2009a) and the gambler's fallacy (e.g., Dohmen et al., 2009b) provides evidence for deviations from rational updating.
} 
dominated the programme of early conferences. Around the turn of the millennium, topics like family and work, retirement behaviour, incentives, skills and technical change, or job satisfaction appeared on the conference programme. In recent years, issues relating to schooling choices, cognitive and noncognitive skills, motivation and incentives, social preferences, risk preferences, and sorting based on skills, preferences and personality traits, are increasingly addressed. The growing concern for the implications of heterogeneity in preferences and personality traits is also apparent. The awareness that individuals differ with respect to economic preferences, such as risk preferences, time preferences, and social preferences and therefore make different decisions, for example with respect to the type of occupations they select, the kind of educational investments they want to make, and the type of incentives they would like to work for, and their responsiveness to particular incentives, has shaped the research questions that have been addressed in recent years.

Another way to gauge whether behavioural economics has left its marks on research interests of the EALE network is to screen the papers that have been published in the association's journal Labour Economics. Figure 3 plots the number of articles published in Labour Economics over the course of its existence that refer to the terms "psychology" or "behavioural".

\section{INSERT FIGURE 3 ABOUT HERE}

The figure reveals that there is a strong rise in articles that refer to psychology and behavioural economics, arguably reflecting an increase in behavioural economics that gained much momentum in the mid of the first decade of the new millennium.

Figures 4 and 5 indicate that the growing interests of labour economics in economics and psychology related mostly to preferences, in particular to social preferences and trust, and more recently to personality. Publications relating to bounded rationality, framing or cognitive biases are comparatively rare. For example, only two papers where published over the entire period that contained the term "bounded rationality", while terms like "fairness" (44 references) and "trust" (68) are more pervasive. This might be a result of the difficulty to formalize and develop standard measures of bounded rationality. In that sense it also reflects a certain degree of opportunism in the profession: we tend to devote attention to problems that are relatively easy to address or for which data is readily available; and a critical mind might state that labour economists behave more often as methodological barbarians rather than Lakatosian research programmers.

\section{Policy implications}

Several implications for firms' personnel policies, the design of optimal incentive schemes, as well as for human capital policies have been mentioned above. In this section, I would like to stress the 
policy implications of behavioural economics for the macro level. Babcock et al. (2012) have sketched the implications of insights from behavioural economics for unemployment compensation, active labour market policies, such as employment services and job search assistance, and training programmes. Policy makers in various western economies have recognized the potential of a behavioural economics approach in policy analysis. In particular the nudge approach in policy making has received much attention and political support in various countries. A prominent example is the UK, which established the "Behavioural Insights Team", in order to apply insights from behavioural economic research to public policy and services.

Similarly, research on the formation of cognitive skills, personality and preferences has attracted much interest from policy makers and the public at large. The conjecture of critical and sensitive periods of investment in early childhood and the evidence for the malleability of noncognitive skills throughout adolescence has shaped recent policy debates in various Western countries. I speculate that research on systematic changes in cognitive skills and preferences at older age will also appeal to policy-makers in aging societies, not only because the timing and speed of cognitive decline affect employability, retirement decisions and the sustainability of the welfare state, but also because changes in the distribution of preferences induced by aging will bring about significant changes in aggregate economic and socio-political outcomes.

\section{Concluding remarks}

Behavioural economics has definitely left its mark on labour economics. This is evident from the rise of articles that apply insights from psychology in the analysis of labour markets. An increasing number of survey articles that sometimes focus on particular aspects of behavioural labour economics, gives proof of the scope of areas within labour economics that have been affected by behavioural economics. The Handbook of Labor Economics Vol. 4, for example, contains 4 chapters that relate to behavioural economics. I expect this trend to continue, not least because there are important research areas in labour economics in which researchers have just begun to apply insights from behavioural economics.

Behavioural economics might not have revolutionized labour economics, but it has certainly reformed the way that (many) labour economists think about the functioning of labour markets. Labour economists have not abandoned the standard economic framework entirely, but have rather tried to incorporate new aspects into existing models. This process is not without frictions. It is clear that psychological motives can be integrated into the standard economic framework in various ways, which almost inevitably results in the unsatisfactory situation that theoretical frameworks diverge. 
Yet, advancement was particularly marked in areas in which theoretical models emerged, as in the literature on social preferences. In other areas, there is, however, an enormous need for the development of theory. As discussed above, theories that integrate concepts from personality psychology in an economic framework seem to be a prerequisite for systematic future scientific progress. Likewise, relaxing the exponential discounting assumption in search models of the labour market seems to be a critical endeavour. In general, amending job search models to account for nonstandard preferences and non-standard beliefs can provide extremely useful insights for macroeconomic models of the labour market.

As theoretical progress is made, there will also be need for empirical evidence to discriminate between opposing ideas concerning the way assumptions of the mainstream model should be modified. In some areas, it even seems that sound empirical work has to precede theory building. One interesting example in that respect is the work on integrating deviations from the exponential discounting model into search models. Whereas the implications for such behaviour in a particular search framework can be theoretically derived, for example, for hyperbolic discounters (see, for example, DellaVigna and Paserman, 2005) it is by no means clear that individuals actually have preferences as described by the hyperbolic discounting model (see, for example, Augenblick et al., 2013; Dohmen et al., 2012). This calls for the development of better elicitation methods. Advances in the measurement of discounting, personality traits and beliefs will certainly catalyse scientific progress in behavioural labour economics.

Another very promising route to follow is to integrate insights from the literature on preference heterogeneity in models of the labour market by relaxing the assumption of the representative agent. Ideally, such models do not only take heterogeneity with respect to a particular preference measure, such as the degree of risk aversion measured in an expected utility framework into account, but rather appreciate the profound heterogeneity of types. Empirical evidence indicates, for example, that a fraction of individuals behaves according to expected utility theory while others' decision-making under risk is better characterized by prospect theory. Likewise, different types with respect to social preferences can be identified. It will be an immense challenge to study how different types interact on the labour market.

I am convinced that behavioural economics will continue to influence labour economics in the future. I am afraid that some labour economists will still associate behavioural economics with the experimental approach, and that controversy over the appropriateness of laboratory experiments for the analysis of labour markets will remain for some more years. I also believe that we will witness new debates between "traditional" labour economists and "behavioural" labour economists. But I hope that labour economics moves ahead. It would be a good sign if the term "behavioural" 
ultimately disappears as an attribute of demarcation of research within the field of labour economics; for what ultimately counts is good economics.

\section{References}

Abbink, K., Irlenbusch, B., Renner, E., 2000. The moonlighting game. Journal of Economic Behavior and Organization 42, 265-277.

Abeler, J., Altmann, S., Kube, S., Wibral, M., 2010. Gift Exchange and Workers' Fairness Concerns: When Equality is Unfair. Journal of the European Economic Association 8(6), 1299-1324.

Abeler, J., Falk, A., Goette, L., Huffman, D., 2011. Reference points and effort provision. The American Economic Review 101(2), 470-492.

Adams, J.S., 1965. Inequity in Social Exchange. In Berkowitz, L. (ed.), Advances in Experimental Social Psychology 2, Academic Press, New York, 267-299.

Agell, J., Lundborg P., 2003. Survey Evidence on Wage Rigidity and Unemployment. Scandinavian Journal of Economics 105, 15-30.

Ainslie, G., 1974. Impulse control in pigeons. Journal of the Experimental Analysis of Behavior 21 (3), 485-489.

Ainslie, G., 1975. Specious Reward: A Behavioral /Theory of Impulsiveness and Impulse Control. Psychological Bulletin 82 (4), 463-496.

Ainslie, G., 1991. Derivation of "rational" economic behavior from hyperbolic discount curves. American Economic Review 81 (2), 334-440.

Akerlof, G.A., 1980. A theory of social custom, of which unemployment may be one consequence. Quarterly Journal of Economics 94, 749-775.

Akerlof, G., 1982. Labor Contracts as Partial Gift-Exchange. Quarterly Journal of Economics 97 (4), 543-569.

Akerlof, G.A., 1997. Social distance and social decisions. Econometrica 65, 1005-1027.

Akerlof, G.A., Shiller, R.J., 2009. Animal Spirits: How Human Psychology Drives the Economy, and Why It Matters for Global Capitalism. Princeton University Press.

Akerlof, G. A., Yellen, J. L., 1990. The fair wage-effort hypothesis and unemployment. The Quarterly Journal of Economics 105(2), 255-283.

Allais, M., 1953. Le Comportement de l'Homme Rationnel devant le Risque, Critique des Postulats et Axiomes de l'Ecole Américaine, Econometrica 21, 503-546. 
Allport G.W., Odbert H.S., 1936. Trait-names: a psycho-lexical study. Psychological Monographs. 47:1-171

Almlund, M., Duckworth, A.L., Heckman, J.J., Kautz, T., 2011. Personality psychology and economics. In E. A. Hanushek, S. Machin, and L. Wößmann (Eds.), Handbook of the Economics of Education Volume 4, 1-181. Amsterdam: Elsevier.

Altmann. S., Falk, A., Grunewald, A., Huffman, D., 2014. Contractual Incompleteness, Unemployment, and Labour Market Segmentation. Review of Economic Studies 81, 30-56.

Angner, E., Loewenstein, G., 2012. Behavioral Economics. In Uskali Mäki (Ed.) Philosophy of Economics vol. 13 of Gabbay, D., Thagard, P., Woods, J. (Eds.) Handbook of the Philosophy of Science, 641-690.

Angrist, J., 2014. Labour Economics, forthcoming.

Ariely, D., 2008. Predictably Irrational - The Hidden Forces that Shape our Decisions. Harper Collins Publishers, New York, NY.

Ariely, D., Gneezy, U., Loewenstein, G., Mazar, N., 2009. Large stakes and big mistakes. The Review of Economic Studies 76(2), 451-469.

Ashraf, N., Camerer, C. F., Loewenstein, G., 2005. Adam Smith, BehavioralEconomist. Journal of Economic Perspectives 19, 131-145.Ashraf, N., Karlan, D., Yin, W., 2006. Tying Odysseus to the Mast: Evidence from a Commitment Savings Product in the Philippines 121 (2), 635-672.

Ashton, M.C., Lee, K., Perugini, M., Szarota, P., de Vries, R.E., Di Blas, L., Boies, K., De Raad, B., 2004. A Six-Factor Structure of Personality-Descriptive Adjectives: Solutions From Psycholexical Studies in Seven Languages. Journal of Personality and Social Psychology 86 (2): 356-366.

Augenblick, N., Niederle, M., Sprenger, C., 2013. Working over time: Dynamic inconsistency in real effort tasks. NBER Working Paper 18734.

Austen-Smith, D., Fryer, R.G., 2005. An economic analysi of 'acting white'. Quarterly Journal of Economics 120, 551-583.

Babcock, L., Congdon, W.J., Katz, L.F., Mullainathan, S., 2012. Notes on behavioral economics and labor market policy. IZA Journal of Labor Policy 2012, 1(2),

Bandiera, O., Barankay, I., Rasul, I., 2005. Social Preferences and the Response to Incentives: Evidence from Personnel Data. Quarterly Journal of Economics 120(3), 917-62. 
Barberis, N., Thaler, R., 2003. A Survey of Behavioral Finance. In Constantinides, G., Harris, M., Stulz, R.M. (Eds.) Handbook of the Economics of finance, Volume 1B, Financial Markets and Asset Pricing. Elsevier, North Holland, 1053-1123.

Bartling, B., von Siemens, F., 2010. The Intensity of Incentives in Firms and Markets: Moral Hazard with Envious Agents. Labour Economics 17, 598-607.

Barmby, T., 2004. A Note on the Labour Supply Behaviour of NYC Cabdrivers: Does Experience Count? Centre for European Labour Market Research Discussion Paper 2004-03.

Barmby, T., \& Dolton, P., 2009. What Lies Beneath? Effort and Incentives on Archaeological digs in the 1930's. Working Paper.

Becker, A., Deckers, T., Dohmen, T., Falk, A., Kosse, F., 2012. The Relationship Between Economic Preferences and Psychological Personality Measures. Annual Review of Economics 4(1), 453-478.

Becker, G.S., Murphy, K.M., 2000. Social Economics. Market Behavior in a Social Environment. Harvard University Press, Cambridge, MA.

Beilock, S. L., Carr, T. H., 2001. On the fragility of skilled performance: What governs choking under pressure? Journal of Experimental Psychology: General, 130(4), 701.

Bellemare, C., Kröger, S., 2007. On Representative Social Capital. European Economic Review 51, $183-$ 202.

Bellemare, C., Shearer, B., 2009. Gift giving and worker productivity: Evidence from a firm-level experiment. Games and Economic Behavior 67(1), 233-244.

Bellemare, C., Shearer, B., 2010. Sorting, Incentives and Risk Preferences: Evidence from a Field Experiment. Economics Letters 108 (3), 345-348.

Berg, J., Dickhaut, J., McCabe, K., 1995. Trust, reciprocity, and social history. Games and Economic Behavior 10, 122-42.

Berg, N., 2006. Behavioral labor economics. Handbook of Contemporary Behavioral Economics. ME Sharp., New York (2006): 457-478.

Berg, N., Gigerenzer, G., 2010. As-if behavioral economics: Neoclassical economics in disguise? MPRA Paper No. 26586.

Berger, J., Harbring, C., Sliwka, D., 2013. Performance Appraisals and the Impact of Forced Distribution-An Experimental Investigation. Management Science 59(1), 54-68.

Bernheim, B.D., 1994. A theory of conformity. Journal of Political Economy 102, 841-877. 
Bernoulli, D., 1954. Exposition of a New Theory on the Measurement of Risk. (original 1738). Econometrica 22, 23-36.

Bewley, T. F., 1999. Why Wages Don't Fall During a Recession. Harvard University Press, Cambridge, MA.

Bewley, T.F., 2007. Fairness, Reciprocity, and Wage Rigidity. Chapter 5 In Diamond, P., Vartiainen, H. (Eds.) Behavioral Economics and its Applications., Princeton University Press. 157-188

Blanchflower, D., Oswald, A., 2011. International Happiness. NBER Working Paper, w16668.

Bonin, H., Dohmen, T., Falk, A., Huffman, D., Sunde, U., 2007. Cross-sectional earnings risk and occupational sorting: The role of risk attitudes. Labour Economics 14(6), 926-937.

Borghans, L., Golsteyn, B.H.H., 2014. The Willingness to Learn of the Life Course. Working Paper. Maastricht University.

Borghans, L., Duckworth, A.L., Heckman, J.J., ter Weel, B. 2008. The Economics and Psychology of Personality Traits. Journal of Human Resources 43(4), 972-1059.

Botti, S., lyengar, S.S.. 2006. The dark side of choice: When choice impairs social welfare. Journal of Public Policy and Marketing 25(1), 24-38.

Bowles, S., 2008. Policies Designed for Self-Interested Citizens May Undermine 'The Moral Sentiments': Evidence from Economic Experiments. Science 320, 1605-1609.

Bowles, S., Gintis, H., Osborne, M., 2001a. Incentive-enhancing preferences: Personality, behavior, and earnings. American Economic Review 91, 155-158.

Bowles, S., Gintis, H., Osborne, M., 2001b. The determinants of earnings: A behavioral approach. Journal of Economic Literature 39(4), 1137-1176.

Bowles, S., Gintis, H., Osborne-Groves, M., 2005. Unequal Chances: Family Background and Economic Success. Princeton University Press.

Brown, M., Falk, A., Fehr, E., 2004. Relational contracts and the nature of market interactions. Econometrica, 72(3), 747-780.

Cable, D. M., Judge, T.A., 1994. Pay preferences and job search decisions: A person-organization fit perspective. Personnel Psychology, 47, 317--348.

Cadsby, C.B., Song, F., Tapon, F., 2007. Sorting and incentive effects of pay for performance: An experimental investigation. Academy of Management Journal 50(2), 387-405.

Caliendo, M., Cobb-Clark, D.,Uhlendorff, A., 2014. Locus of Control and Job Search Strategies. Review of Economics and Statistics, forthcoming. 
Caliendo, M., Fossen, F.M., Kritikos, A.S., 2009. Risk attitudes of nascent entrepreneurs-new evidence from an experimentally validated survey. Small Business Economics 32(2), 153-167.

Camerer, C.F., Loewenstein, G., 2004. Behavioral economics: Past, present, future. In Camerer, C. F., Loewenstein, G., Rabin, M. (eds.) Advances in Behavioral Economics, 3-51. New York and Princeton: Russell Sage Foundation Press and Princeton University Press.

Camerer, C.F., 2006. Behavioral Economics. In Blundell, R., Newey, W.K., Persson, T. (eds.) Advances in Economics and Econometrics: Theory and Applications, Ninth World Congress, Volume 2, 181-214. Cambridge and New York: Cambridge University Press.

Camerer, C.F., Thaler, R.H., 1995. Anomalies: Ultimatums, dictators and manners. Journal of Economic Perspectives 9(2), 209-219.

Camerer, C.F., Babcock, L., Loewenstein, G., Thaler, R., 1997. Labor supply of New York City cabdrivers: One day at a time. The Quarterly Journal of Economics 112(2), 407-441.

Caplin, A., Martin, D.J., forthcoming. A Testable Theory of Imperfect Perception. Economic Journal.

Cappelen, A.W., Nygaard, K., Sørensen, E. Ø., Tungodden, B., 2014. Social preferences in the lab: A comparison of students and a representative population. Scandinavian Journal of Economics, forthcoming.

Card, D., Mas, A., Moretti, E., Saez, E., 2012. Inequality at Work: the Effect of Peer Salaries on Job Satisfaction, American Economic Review 112.

Carneiro, P., Heckman, J.J., Human Capital Policy. in Heckman, J.J., Krueger, A. (eds). Inequality in America: What Role for Human Capital Policy?, MIT Press, 2003.

Case, Anne, and Christina Paxson. 2008. Stature and status: Height, ability, and labor market outcomes. Journal of Political Economy 116(3), 499-532.

Chabris, C., D. Laibson, C. Morris, J. Schuldt, and D. Taubinsky (2008): Individual laboratory-measured discount rates predict field behavior," Journal of Risk and Uncertainty 37(2), 237-269.

Charness, G., \& Kuhn, P. (2011). Lab labor: What can labor economists learn from the lab?. Handbook of labor economics, 4, 229-330.

Chetty, R., Looney, A., Kroft, K., 2009. Salience and Taxation: Theory and Evidence. The American Economic Review, 99(4), 1145-1177.

Choi, J. J., Laibson, D., Madrian, B. C., 2004. Plan Design and 401 (k) Savings Outcomes. National Tax Journal, 275-298. 
Choi, J. J., Laibson, D., Madrian, B. C., 2009. Reducing the Complexity Costs of 401 (k) Participation through Quick Enrollment. In Wise, D. (ed.) Developments in the Economics of Aging, University of Chicago Press, 57-.

Chou, Y. K., 2002. Testing alternative models of labor supply: Evidence from cab drivers in Singapore. The Singapore Economic Review 47(1), 17-47.

Clark, A. E., Frijters, P., Shields, M. A., 2008. Relative income, happiness, and utility: An explanation for the Easterlin paradox and other puzzles. Journal of Economic Literature 46(1), 95-144.

Clark, A.E., Masclet, D., Villeval, M.-C., 2010. Effort and Comparison Income: Experimental and Survey Evidence. Industrial and Labor Relations Review 63 (3), 407-426.

Clark, A. E., Oswald, A. J, 1994. Unhappiness and unemployment. Economic Journal 104(424), 648-59.

Clark, A.E., Oswald, A.J.,1996. Satisfaction and Comparison Income. Journal of Public Economics 61(3), 359-381.

Cohn A., Fehr E., Goette L., 2014. Fair wages and effort provision: Combining evidence from the lab and the field. Management Science, forthcoming.

Cohn, A., Fehr, E., Herrmann, B., Schneider, F., 2014. Social comparison and effort provision: evidence from a field experiment. Journal of the European Economic Association, forthcoming Colander, D., 2000. The Death of Neoclassical Economics. Journal of the History of Economic Thought 22(2), 127-143.

Coleman, J.S., 1990. Foundations of Social Theory. The Belknap Press of Harvard University Press, Cambridge, MA.

Cockx, B., Ghirelli, C., Van der Linden, B., 2014. Is it Socially Efficient to Impose Job Search Requirements on Unemployed Benefit Claimants with Hyperbolic Preferences?. Journal of Public Economics 113, 80-95.

Costa, P.T., McCrae, R.R., 1992a. Four Ways Five Factors Are Basic. Personality and Individual Differences 13(6), 653-665.

Costa, P.T., McCrae, R.R., 1992b. Revised NEO Personality Inventory (NEO PI-R) and NEO Five-Factor Inventory (NEO-FFI). Odessa, FL, Psychological Assessment Resources.

Cramer, J., Hartog, J., Jonker, N., van Praag, C. M., 2002. Low Risk Aversion Encourages the Choice for Entrepreneurship: An Empirical Test of a Truism. Journal of Economic Behavior and Organization 48(1), 29-36. 
Crawford, V.P., Meng, J., 2011. New York City cab drivers' labor supply revisited: Referencedependent preferences with rational expectations targets for hours and income. American Economic Review 101(5), 1912-1932.

Cunha, F., Heckman, J.J., 2007. The Technology of Skill Formation. American Economic Review 97(2), 31-47.

Cunha, F., Heckman, J.J., 2009. The Economics and Psychology of Inequality and Human Development. Journal of the European Economic Association 7(2-3), 320-364.

Cunha, F., Heckman, J.J., Lochner, L.J., Masterov, D.V., 2006. Interpreting the evidence on life cycle skill formation. In Hanushek, E.A., Welch, F., (eds.) Handbook of the economics of education, Amsterdam: North-Holland, 697-812.

Dawes, R.M., Thaler, R.H., 1988. Anomalies: Cooperation. Journal of Economic Perspectives 2(3), 187197.

De Grip, A., Sauermann, J., 2012. The Effects of Training on Own and Co-worker Productivity: Evidence from a Field Experiment. The Economic Journal 122(560), 376-399.

DeLeire, T., Levy, H., 2004. Worker sorting and the risk of death on the job. Journal of Labor Economics 22(4), 925-953.

DellaVigna, S., Paserman, M.D., 2005. Job Search and Impatience. Journal of Labor Economics 23, 527-588.

DellaVigna, S., 2009. Psychology and Economics: Evidence from the Field. Journal of Economic Literature 47(2), 315-372.

De Neve, J. E., \& Oswald, A. J. (2012). Estimating the influence of life satisfaction and positive affect on later income using sibling fixed effects. Proceedings of the National Academy of Sciences, 109(49), 19953-19958.

Diamond, P., Vartiainen, H., 2007. Behavioral Economics and its Applications., Princeton University Press.

Dohmen, T. 2008a. The influence of social forces: Evidence from the behavior of football referees. Economic Inquiry 46(3), 411-424.

Dohmen, T., 2008b. Do professionals choke under pressure?. Journal of Economic Behavior \& Organization 65(3), 636-653.

Dohmen, T., Falk, A., 2010. You get what you pay for: Incentives and selection in the education system. The Economic Journal 120(546), F256-F271. 
Dohmen, T., Falk, A., 2011. Performance pay and multidimensional sorting: Productivity, preferences, and gender. The American Economic Review 101(2), 556-590.

Dohmen, T., Falk, A., Huffman. D., Sunde, U., 2009. Homo Reciprocans: Survey Evidence on Behavioral Outcomes, Economic Journal 119(536), 592-612.

Dohmen, T., Falk, A., Huffman, D., Marklein, F., Sunde, U., 2009a. The Non-Use of Bayes Rule: Representative Evidence on Bounded Rationality. ROA Research Memorandum 2009/1.

Dohmen, T., Falk, A., Huffman, D., Marklein, F., Sunde, U., 2009b. Biased probability judgment: Evidence of incidence and relationship to economic outcomes from a representative sample. Journal of Economic Behavior and Organization 72(3), 903-915.

Dohmen, T., Falk, A., Fliessbach, K., Sunde, U., Weber, B., 2011b. Relative versus absolute income, joy of winning, and gender: Brain imaging evidence. Journal of Public Economics 95(3), 279-285.

Dohmen, T., Falk, A., Huffman. D., Sunde, U., 2010. Are risk aversion and impatience related to cognitive ability? American Economic Review 100(3), 1238-1260.

Dohmen, T., Falk, A., Huffman, D., Sunde, U., 2012a. Interpreting Time Horizon Effects in Intertemporal Choice. IZA Discussion Paper No. 6385.

Dohmen, T., Falk, A., Huffman, D., Sunde, U., 2012b. The Intergenerational Transmission of Risk and Trust Attitudes. Review of Economic Studies 79(2), 645-677.

Dohmen, T., Falk, A., Huffman, D., Sunde, U., Schupp, J., Wagner, G.G., 2011a. Individual Risk Attitudes: Measurement, Determinants and Behavioral Consequences. Journal of the European Economic Association 9(3), 522-550.

Donohue, J.J., Heckman, J.J., 1991. Continuous versus Episodic Chance: The Impact of Civil Rights Policy on the Economic Status of Blacks. Journal of Economic Literature 29 (4), 1603-1643.

Donkers, B., Melenberg, B., Soest, A.V., 2001. Estimating Risk Attitudes Using Lotteries: A Large Sample Approach. Journal of Risk and Uncertainty 22(2), 165-195.

Doran, K. B., 2009. The existence and position of daily income reference points: Implications for daily labor supply. University of Notre Dame Discussion Paper.

Doyle, J.R., 2013. Survey of time preference, delay discounting models. Judgment and Decision Making 8(2), 116-135.

Dufwenberg, M., Kirchsteiger, G., 2004. A Theory of Sequential Reciprocity. Games \& Economic Behavior 47, 268-98. 
Dunn, L.F., 1996. Loss Aversion and Adaptation in the Labor Market: Empirical Indifference Functions and Labor Supply. Review of Economics and Statistics 78: 441-50.

Duesenberry, J. S. 1949. Income, Saving, and the Theory of Consumer Behavior. Cambridge and London: Harvard University Press.

Ekelund, J., Johansson, E., Jarvelin, M., Lichtermann, D., 2005. Self-employment and risk aversion: evidence from psychological test data. Labour Economics 12(5), 649-659.

Engel, C., 2011. Dictator games: a meta study. Experimental Economics 14(4), 583-610.

Engelmann, D., Strobel, M., 2004. Inequality Aversion, Efficiency, and Maximin Preferences in Simple Distribution Experiments. American Economic Review 94(4), 857-869.

Eriksson, T., Teyssier, S., Villeval, M.C., 2009. Self-selection and the efficiency of tournaments. Economic Inquiry 47(3), 530-548.

Falk, A., Becker, A., Dohmen, T., Huffman, D., Sunde, U., 2014. An Experimentally-Validated Survey Module of Economic Preferences. Working Paper, University of Bonn.

Falk, A., Fehr, E., Fischbacher, U., 2008. Testing Theories of Fairness - Intentions Matter. Games and Economic Behavior 62, 287-303.

Falk, A., Fehr, E., 2003. Why Labour Market Experiments? Labour Economics 10, 399-406.

Falk, A., Fehr, E., Zehnder, C., 2006. Fairness perceptions and reservation wages-the behavioral effects of minimum wage laws. The Quarterly Journal of Economics 121(4), 1347-1381.

Falk, A., Fischbacher, U., 2006. A Theory of Reciprocity. Games and Economic Behavior 54(2), 293315.

Falk, A., Heckman, J.J., 2009. Lab Experiments Are a Major Source of Knowledge in the Social Sciences. Science 326, 535-538.

Falk, A., Huffman, D., MacLeod, W. B., 2008. Institutions and contract enforcement. National Bureau of Economic Research. (No. w13961).

Falk, A., Huffman, D., Sunde, U. (2006). Self-confidence and search (No. 2525). IZA Discussion Papers. Falk, A., Ichino, A., 2006. Clean Evidence on Peer Effects. Journal of Labor Economics, 24(1), 39-57.

Falk, A., Kosse, F., Menrath, I., Verde, P. E., Siegrist, J., 2013. Unfair Pay and Health. Working Paper, University of Bonn.

Falk, A., Maier, S., Zehnder, C., 2013. Do Lab Experiments Misrepresent Social Preferences? The Case of Self-Selected Student Samples. Journal of the European Economic Association 11(4), 839-852. 
Farber, H. S., 2005. Is tomorrow another day? The labor supply of New York City cabdrivers', Journal of Political Economy 113(1), 46-82.

Farber, H.S., 2008. Reference-dependent preferences and labor supply: The case of New York City taxi drivers. The American Economic Review 98(3), 1069-1082.

Fehr, E., Falk, A., 1999. Wage Rigidity in a Competitive Incomplete Contract Market. Journal of Political Economy 107(1), 106-134.

Fehr, E., Falk, A., 2002. Psychological Foundations of Incentive. European Economic Review 46, 687724.

Fehr, E., Gächter, S., 2000a. Fairness and Retaliation. Journal of Economic Perspectives 14(3), 159181.

Fehr, E., Gächter, S., 2000b. Cooperation and Punishment in Public Goods Experiments. American Economic Review 90(4), 980-994.

Fehr, E., Gächter, S., 2002. Do Incentive Contracts Undermine Voluntary Cooperation? Institute for Empirical Research in Economics University of Zurich, Working Paper No. 34.

Fehr, E., Goette, L., 2007. Do workers work more if wages are high? Evidence from a randomized field experiment. American Economic Review 97(1), 298-317.

Fehr, E., Goette, L., Zehnder, C., 2009. A Behavioral Account of the Labor Market: The Role of Fairness Concerns. Annual Review of Economics 1, 355-384.

Fehr, E., Kirchsteiger, G., Riedl, A., 1993. Does Fairness Prevent Market Clearing? An Experimental Investigation. Quarterly Journal of Economics 108(2), 437-459.

Fehr, E., Schmidt, K.L., 1999. A Theory of Fairness, Competition and Cooperation. Quarterly Journal of Economics 114, 817-868.

Fehr, E., Schmidt, K.L., 2006. The Economics of Fairness, Reciprocity and Altruism - Experimental Evidence and New Theories. In Kolm, S.-C.,Mercier Ythier, J. (Eds.), Handbook of The Economics of Giving, Altruism and Reciprocity, Elsevier, North-Holland, 615-691.

Fehr, E., Tyran, J.R., 2001. Does money illusion matter?. American Economic Review, 1239-1262.

Festinger, L., 1954. A theory of social comparison processes. Human relations 7(2), 117-140.

Filer, R.K., 1981. The Influence of Affective Human Capital on the Wage Equation. Research in Labor Economics, 367-416.

Fischbacher, U., Gächter, S., 2010. Social preferences, beliefs, and the dynamics of free riding in public goods experiments. American Economic Review 100(1), 541-556. 
Fischbacher, U., Gächter, S., Fehr, E., 2001. Are People Conditionally Cooperative? Evidence from a Public Goods Experiment. Economics Letters 71(3), 397-404.

Fliessbach, K., Weber, B., Trautner, B., Dohmen, T., Sunde, U., Elger, C.E., Falk, A., 2007. Social comparison affects reward-related brain activity in the human ventral striatum. Science 318, 13051308.

Frank, R. H., 1984. Are workers paid their marginal products?. American Economic Review 74(4), 54971.

Frank, R. H., 1985a. The demand for unobservable and other nonpositional goods. The American Economic Review 101-116.

Frank, R. H., 1985b. Choosing the Right Pond: Human Behavior and the Quest for Status. Oxford University Press.

Frank, R.H., 2005. Positional externalities cause large and preventable welfare losses. American Economic Review 95, 137-141

Frank, R. H., Hutchens, R. M., 1993. Wages, seniority, and the demand for rising consumption profiles. Journal of Economic Behavior \& Organization 21(3), 251-276.

Frederick, S., Loewenstein, F., O'Donoghue, T., 2002. Time Discounting and Time Preference: A Critical Review. Journal of Economic Literature 40, 351-401.

Frey, B. S., Stutzer, A., 2002. What can economists learn from happiness research? Journal of Economic Literature 40(2), 402-435.

Funder, D. C., 2001. Personality. Annual Review of Psychology 52, 197-221.

Gächter, S., Falk, A.,2002. Reputation and reciprocity: Consequences for the labour relation. The Scandinavian Journal of Economics 104(1), 1-26.

Gächter, S., Fehr, E., 2002. Fairness in the labour market. In Bolle, F., Lehmann-Waffenschmidt, M., Surveys in Experimental Economics. Contribution to Economics. Physica-Verlag HD, 95-132.

Gächter, S., Renner, E., Sefton, M., 2008. The long-run benefits of punishment. Science 322(5907), 1510-1510.

Gächter, S., Thöni, C., 2010. Social comparison and performance: Experimental evidence on the fair wage-effort hypothesis. Journal of Economic Behavior \& Organization 76, 531-543.

Garicano, L., Palacios-Huerta, I., Prendergast, C., 2005. Favoritism under social pressure. Review of Economics and Statistics 87(2), 208-216. 
Gintis, H., 2009. The Bounds of Reason: Game Theory and the Unification of the Behavioral Sciences. Princeton University Press: Princeton, NJ.

Gneezy, U., List, J.A., 2006. Putting behavioral economics to work: Testing for gift exchange in labor markets using field experiments. Econometrica 74(5), 1365-1384.

Goette, L., Huffman, D., Fehr, E. (2004). Loss aversion and labor supply. Journal of the European Economic Association, 2(2-3), 216-228.

Güth, W., Schmittberger, R., Schwarze, B., 1982. An Experimental Analysis of Ultimatum Bargaining. Journal of Economic Behavior and Organization 3(4): 367-88.

Guerin, B., 1993. Social Facilitation. Cambridge University Press, Cambridge, MA.

Gul, F., 2008. Behavioural economics and game theory. The New Palgrave Dictionary of Economics. Second Edition. Eds. Steven N. Durlauf and Lawrence E. Blume. Palgrave Macmillan, 2008. The New Palgrave Dictionary of Economics Online. Palgrave Macmillan. 21 March 2014 <http://www.dictionaryofeconomics.com/article?id=pde2008_G000210> doi:10.1057/9780230226203.0115

Hamermesh, D., 1975. Interdependence in the Labor Market. Economica 42, 420-429.

Hamermesh, D.S., Biddle, J.E., 1994. Beauty and the Labor Market. American Economic Review 84(5), 1174-1194.

Hansen, K.T., Heckman, J.J., Mullen, K., 2004. The Effect of Schooling and Ability on Achievement Test Scores. Journal of Econometrics 121(1-2), 39-98.

Harrison, G.W., Lau, M.I., Rutström, E.E., 2007. Estimating Risk Attitudes in Denmark: A Field Experiment. Scandanavian Journal of Economics 109(2), 341-368.

Harrison, G.W., Lau, M.I., Williams, M.B., 2002. Estimating Individual Discount Rates in Denmark: A Field Experiment. American Economic Review 92(5), 1606-1617.

Hartog, J., 2001. On human capital and individual capabilities. Review of Income and Wealth 47(4), 515-540.

Hartog, J., Diaz-Serrano, L., 2013. Schooling as a Risky Investment: A Survey of Theory and Evidence. Foundation and Trends in Microeconomics 9(3-4), 159-331.

Hartog, J., Plug, E., Diaz-Serrano, L., Vieira, J., 2003. Risk compensation in wages - A replication. Empirical Economics 28(3), 639-647.

Heckman, J.J., Rubinstein, Y., 2001. The Importance of Noncognitive Skills: Lessons from the GED Testing Program. American Economic Review 91, 145-149. 
Heckman, J.J., Stixrud, J., Urzua, S., 2006. The Effects of Cognitive and Noncognitive Abilities on Labor Market Outcomes and Social Behavior. Journal of Labor Economics 24(3), 411-482.

Heineck, G., Anger, S., 2010. The returns to cognitive abilities and personality traits in Germany. Labour Economics 17(3), 535-546.

Henrich, J., Heine, S.J., Norenzayan. A., 2010. The weirdest people in the world? Behavioral and Brain Sciences 33(2-3), 61-135.

Herrnstein, R. J., Murray, C. A., 1994. The bell curve: Intelligence and class structure in American life. New York: Free Press.

Holt, C.A., Laury, S.K., 2002. Risk Aversion and Incentive Effects. American Economic Review 92(5), 1644-1655.

Jencks, C., 1979. Who Gets Ahead? New York: Basic Books.

Juster, F. T., 1991. Rethinking Utility Theory: A Summary Statement. In Etzioni, A., Lawrence, P. (eds), Socio-Economics: Toward a New Synthesis. Armonk, N.Y.: M.E. Sharp, pp. 85-104.

Kahneman, D., Knetsch, J.L., Thaler, R.H., 1986. Fairness and the Assumptions of Economics. Journal of Business 59(4), 285-300.

Kahneman, D., Knetsch, J.L., Thaler, R.H., 1990. Experimental Tests of the Endowment Effect and the Coase Theorem. Journal of Political Economy 98(6), 1325-48.

Kahneman, D., Knetsch, J.L., Thaler, R.H., 1991. Anomalies: The endowment effect, loss aversion, and status quo bias. The Journal of Economic Perspectives 5(1), 193-206.

Kahneman, D., Tversky, A., 1979. Prospect Theory: An Analysis of Decision under Risk. Econometrica 47(2), 263-91.

Kamenica, E., 2012. Behavioral economics and psychology of incentives. Annual Review of Economics $4(1), 427-452$.

Kaufman, B.E., 1999. Expanding the Behavioral Foundations of Labor Economics. Industrial and Labor Relations Review 52, 361-92.

Keynes, J.M., 1936. The General Theory of Employment, Interest and Money. Macmillan Cambridge University Press.

Kőszegi, B., Rabin, M., 2006. A Model of Reference-Dependent Preferences. Quarterly Journal of Economics 121(4), 1133-65.

Kőszegi, B., Szeidl, A., 2013. A model of focusing in economic choice. The Quarterly Journal of Economics, 128(1), 53-104. 
Krueger, A.B., Mas, A., 2004. Strikes, Scabs, and Tread Separations: Labor Strife and the Production of Defective Bridgestone/Firestone Tires. Journal of Political Economy, 112(2), 253-289

Kube, S., Maréchal, M.A., Puppe, C., 2013. Do Wage Cuts Damage Work Morale? Evidence from a Natural Field Experiment. Journal of the European Economic Association, 2013, 11(4), 853-870.

Kube, S., Puppe, C., Maréchal, M.A., 2012. The Currency of Reciprocity - Gift-Exchange in the Workplace. American Economic Review 102(4), 1644-1662.

Laibson, D., 1997. Golden Eggs and Hyperbolic Discounting. Quarterly Journal of Economics 112(2), 443-477.

Larkin, I., Leider, S., 2012. Incentive schemes, sorting, and behavioral biases of employees: Experimental evidence. American Economic Journal: Microeconomics 4(2), 184-214.

Lazear, E. P., 2000. Performance Pay and Productivity. American Economic Review 90(5), 1346-61.

Levine, D.K., 1998. Modeling Altruism and Spitefulness in Experiments. Review of Economic Dynamics, 1, 593-622.

Levitt, S. D., List, J. A., 2007. What do laboratory experiments measuring social preferences reveal about the real world?.Journal of Economic Perspectives, 153-174.

Lindqvist, E., 2012. Height and leadership. Review of Economics and Statistics 94(4), 1191-1196.

List, J. A., 2003. Does Market Experience Eliminate Market Anomalies? Quarterly Journal of Economics 118(1), 41-71.

List, J.A., 2008. Homo experimentalis Evolves. Science 321, 207-208.

Loehlin, J., Horn, J., Willerman, L., 1981. Personality Resemblance in Adoptive Families. Behavior Genetics 11, 309-330.

Loewenstein, G., Thaler, R.H., 1989. Anomalies: Intertemporal Choice. The Journal of Economic Perspectives 3(4), 181-193.

Luttmer, E., 2005. Neighbors as negatives: Relative earnings and well-being. Quarterly Journal of Economics 120, 963-1002.

Mas, A., 2006. Pay, Reference Points, and Police Performance. Quarterly Journal of Economics 121(3), 783-821.

Mas, A., 2008. Labour Unrest and the Quality of Production: Evidence from the Construction Equipment Resale Market. Review of Economic Studies, 75(1), 229-258.

Mas, A., Moretti, E., 2009. Peers at Work. American Economic Review 99(1), 112-145. 
McClure, S.M., et al., 2005. Separate Neural Systems Value Immediate and Delayed Monetary Rewards. Science 306, 503-509.

McGee, A., McGee, P., 2011. Search, Effort, and Locus of Control. IZA Discussion Paper 5948.

National University of Singapore Mellström, C., Johannesson, M., 2008. Crowding Out in Blood Donation: Was Titmuss Right? Journal of the European Economic Association 6(4), 845-863.

Mischel, W., Metzner, R., 1962. Preference for Delayed Reward as a Function of Age, Intelligence, and Length of Delay Interval. The Journal of Abnormal and Social Psychology 64(6), 425-31.

Mischel, W., Shoda, Y., Rodriguez, M. L., 1989. Delay of gratification in children. Science 244, 933938.

Moffitt, T. E., Arseneault, L., Belsky, D., Dickson, N., Hancox, R. J., Harrington, H., Houts, R., Poulton, R., Roberts, B. W., Ross, S., Sears, M.R., Thomson, W.M., Caspi, A. , 2011. A gradient of childhood self-control predicts health, wealth, and public safety. Proceedings of the National Academy of Sciences, 108(7), 2693-2698.

Montizaan, R., Cörvers, F., de Grip, A., Dohmen, T., 2012. Negative Reciprocity and Retrenched Pension Rights. IZA Discussion Paper 6955.

Mueller, G., Plug, E., 2006. Estimating the Effect of Personality on Male and Female Earnings. Industrial and Labor Relations Review 60(1), 3-22.

Mullainathan, S., Thaler, R.H., 2001. Behavioral Economics. In International Encyclopedia of the Social and Behavioral Sciences, Volume 20, ed. Neil J. Smelser and Paul B. Baltes, 1094-1100. Oxford and New York: Oxford University Press.

Munasinghe, L., Sicherman, N., 2000. Why Do Dancers Smoke? Time Preference, Occupational Choice, and Wage Growth. NBER Working Paper W7542.

Nagel, R., 1995. Unraveling in Guessing Games: An Experimental Study. American Economic Review 85 (5), 1313-1326.

Neal, D.A., Johnson, W.R., 1996. The Role of Premarket Factors in Black-White Wage Differences. Journal of Political Economy 104(5), 869-895.

Neumark, D., Postlewaite, A., 1998. Relative income concerns and the rise in married women's employment. Journal of Public Economics 70(1), 157-183.

Niederle, M., Vesterlund, L., 2007. Do women shy away from competition? Do men compete too much? The Quarterly Journal of Economics 122(3), 1067-1101. 
Ockenfels, A., Sliwka, D.,Werner, P., 2014. Bonus Payments and Reference Point Violations. Management Science, forthcoming

O'Donoghue, T., Rabin, M., 1999. Doing It Now or Later. The American Economic Review 89(1), 103124.

O'Donoghue, T., Rabin, M., 2001. Choice and procrastination. The Quarterly Journal of Economics 116(1), 121-160.

Oettinger, G.S., 1999. An Empirical Analysis of the daily Labor supply of Stadium Vendors. Journal of Political Economy 107(2), 360-392.

J. M. Olson, C. P. Herman, M. P. Zannan (Eds.), 1986. Relative Deprivation and Social Comparison. Lawrence Erlbaum, Hillsdale, NJ.

Oswald, A.J., Proto, E., Sgroi, D., forthcoming. Happiness and Productivity. Journal of Labor Economics.

Parsons, C. A., Sulaeman, J., Yates, M. C., Hamermesh, D. S., 2011. Strike three: discrimination, incentives, and evaluation. The American Economic Review 101(4), 1410-1435.

Paserman, M. D. (2008). Job Search and Hyperbolic Discounting: Structural Estimation and Policy Evaluation*. The Economic Journal 118(531), 1418-1452.

Persky. J., 1995. Retrospectives: The ethology of Homo economicus. Journal of Economic Perspectives 9(2), 221-231.

Persico, N., Postlewaite, A., Silverman, D., 2004. The Effect of Adolescent Experience on Labor Market Outcomes: The Case of Height. Journal of Political Economy 112(5), 1019-1053.

Piatek, R.,Pinger, P., 2010. Maintaining (Locus of) Control? Assessing the Impact of Locus of Control on Education Decisions and Wages, IZA Discussion Papers 5289.

Pollak, R. A., 1976. Interdependent preferences. American Economic Review 66(3), 309-320.

Prendergast, C., 1993. A Theory of" Yes Men". American Economic Review 83(4), 757-770.

Quiggin, J., 1982. A Theory of Anticipated Utility. Journal of Economic Behavior and Organization 3(4), 323-343.

Rabin, M., Weizsäcker, G., 2009. Narrow Bracketing and Dominated Choices. American Economic Review 99(4), 1508-43.

Rabin, M., 1993. Incorperating fairness into game theory and economics. American Economic Review 83(5), 1281-1302.

Rabin, M., 1998. Psychology and Economics. Journal of Economic Literature, 36(1), 11-46. 
Rabin, M., 2002a. Inference by Believers in the Law of Small Numbers. Quarterly Journal of Economics , 117(3), 775-861.

Rabin, M., 2002b. A Perspective on Psychology and Economics. European Economic Review, 46(4-5), 657-685.

Rabin, M., Thaler, R.H., 2001. Anomalies: risk aversion. Journal of Economic Perspectives 15(1) , 219232.

Rabin, M., Thaler, R.H., 2002. Response [anomalies: risk aversion]. Journal of Economic Perspectives, 16(2), 229-230.

Rebitzer, J. B., Taylor, L. J., 2011. Extrinsic rewards and intrinsic motives: standard and behavioral approaches to agency and labor markets. Handbook of Labor Economics 4A, 701-772.

Robbins, L., 1932. An Essay on the Nature and Significance of Economic Science. London: Macmillan.

Roberts, B.W., 2009. Back to the Future: Personality and Assessment and Personality Development. Journal of Research in Personality 43(2), 137-145.

Roberts, B.W., Kuncel, N.R., Shiner, R., Caspi, A., Goldberg, L.R., 2007. The Power of Personality: The Comparative Validity of Personality Traits, Socioeconomic Status, and Cognitive Ability for Predicting Important Life Outcomes. Perspectives on Psychological Science 2. 313-345.

Santos-Pinto, L., 2008. Positive Self-image and Incentives in Organisations. Economic Journal 118(531), 1315-1332.

Santos-Pinto, L., 2010. Positive Self-Image in Tournaments. International Economic Review 51(2), 475-496.

Santos-Pinto, L., 2012. Labor Market Signaling and Self-Confidence: Wage Compression and the Gender Pay Gap. Journal of Labor Economics 30(4), 873-914.

Schmeidler, D., 1989. Subjective Probability and Expected Utility without Additivity. Econometrica 57 (3), 571-587.

Segal, U., Sobel, J. 2007. Tit for tat: Foundations of preferences for reciprocity in strategic settings. Journal of Economic Theory 136(1), 197-216.

Simon, H.A., 1955. A Behavioral Model of Rational Choice. Quarterly Journal of Economics, 69(1), 99118.

Smith, A., 1759 [1981]. The Theory of Moral Sentiments. Raphael, D.D., Macfie, A.L. (eds.) Liberty Fund: Indeanapolis. 
Smith, A., 1776 [1976]. An Inquiry into the Nature and Causes of the Wealth of Nations. Campbell, R.H., Skinner, A.S., Todd, W.B. (eds.) Liberty Fund: Indeanapolis.

Sobel, J., 2005. Interdependent Preferences and Reciprocity. Journal of Economic Literature 43(2), 392-436.

Spinnewijn, J., forthcoming. Optimal Insurance Design with Biased Beliefs. Journal of the European Economic Association.

Stark, O., Hyll, W., 2011. On the economic architecture of the workplace: Repercussions of social comparisons among heterogeneous workers. Journal of Labor Economics 29(2), 349-375.

Starmer, C., 2000. Developments in Non-expected Utility Theory: The Hunt for a Descriptive Theory of Choice under Risk. Journal of Economic Literature 38(2), 332-382.

Thaler, R.H., 1988. Anomalies: The ultimatum game. The Journal of Economic Perspectives 2(4), 195206.

Thaler, R.H., 1989. Interindustry wage differentials. Journal of Economic Perspectives 3(2), 181-193.

Thaler, R.H., Benartzi, S.,2004. Save More Tomorrow ${ }^{\mathrm{TM}}$ : Using behavioral economics to increase employee saving. Journal of Political Economy 112(S1), S164-S187.

Thaler, R.H., Mullainathan, S., 2008. How Behavioral Economics Differs from Traditional Economics. The Concise Encyclopedia of Economics.

Thaler, R.H., Sunstein, C.R., 2008. Nudge: Improving Decisions About Health, Wealth, and Happiness. Yale University Press.

Tinbergen, J., 1956. On the Theory of Income Distribution. Weltwirtschaftliches Archiv 77, 155-175.

Triplett, N., 1898. The dynamogenic factors in pacemaking and competition. American Journal of Psychology 9, 507-533.

Tversky, A., Kahneman, D., 1974. Judgment under Uncertainty: Heuristics and Biases. Science, 185(4157), 1124-1131.

Tversky, A., Kahneman, D., 1981. The Framing of Decisions and the Psychology of Choice. Science, 211(4481), 453-458.

von Neumann, J., Morgenstern, O., 1947. The Theory of Games and Economic Behaviour. $2^{\text {nd }}$ ed. Princeton University Press.

Weber, B., Rangel, A., Wibral, M., Falk, F., 2009. The medial prefrontal cortex exhibits money illusion. Proceedings of the National Academy of Sciences 106(13), 5025-5028. 
Weber, R., Dawes, R., 2010. Behavioral economics. Chapter 5 in Smelser, N. J., Swedberg, R. (eds.), The Handbook of Economic Sociology (2nd ed.), 90-108. Princeton: Princeton University Press

Veblen, T., 1899. The Theory of the Leisure Class. London: Macmillan, George Allen and Unwin.

Weintraub, E.R., 2002. How Economics Became a Mathematical Science. Duke University Press.

Wilson, C. M., Garrod, L., Munro, A., 2013. Default effects, transaction costs, and imperfect information. Economics Letters 119(2), 213-215. 
Figure 1: Proliferation of gift-exchange literature - annual number of citations of selected papers according to Google Scholar.

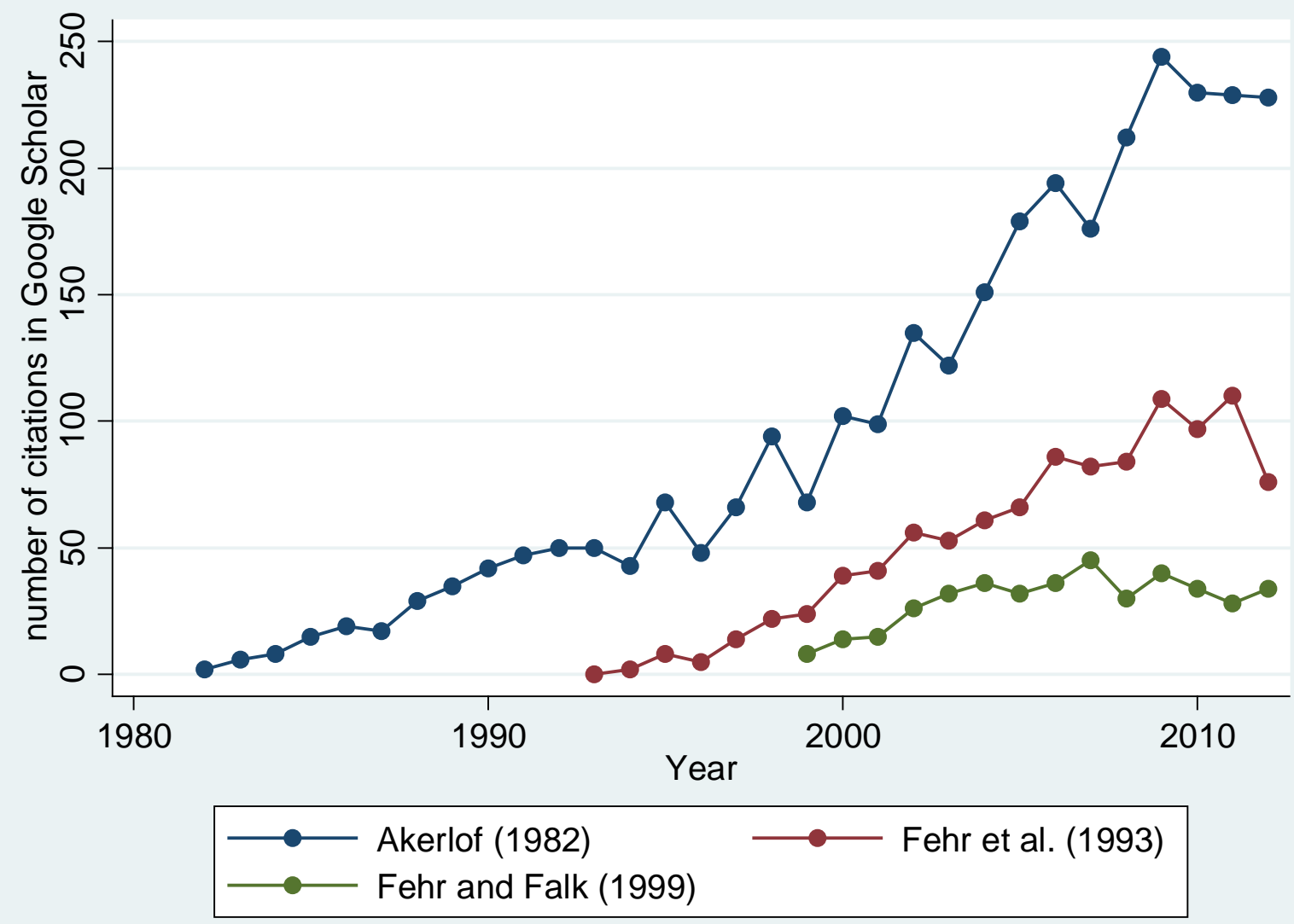

Notes: Source: Information retrieved from http://scholar.google.de/ on November 30, 2013; own counts 
Figure 2: Impact of non-exponential discounting on labour economics relative its impact on economics at large - comparison of annual number of citations of selected papers according to Google Scholar.

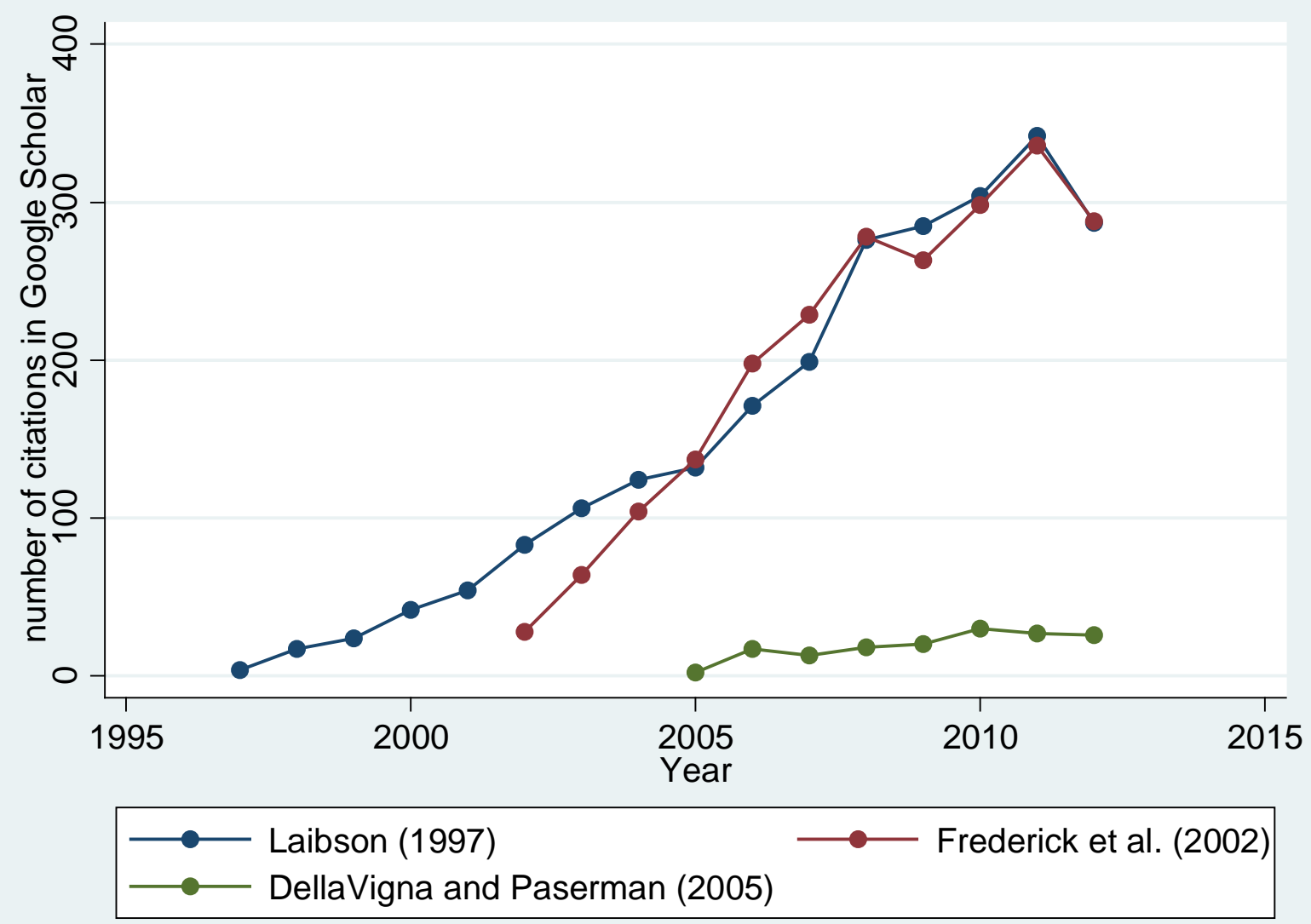

Notes: Source: Information retrieved from http://scholar.google.de/ on November 30, 2013; own counts 
Figure 3: Number of articles published in Labour Economics referring to "psychology" and "behavioural"

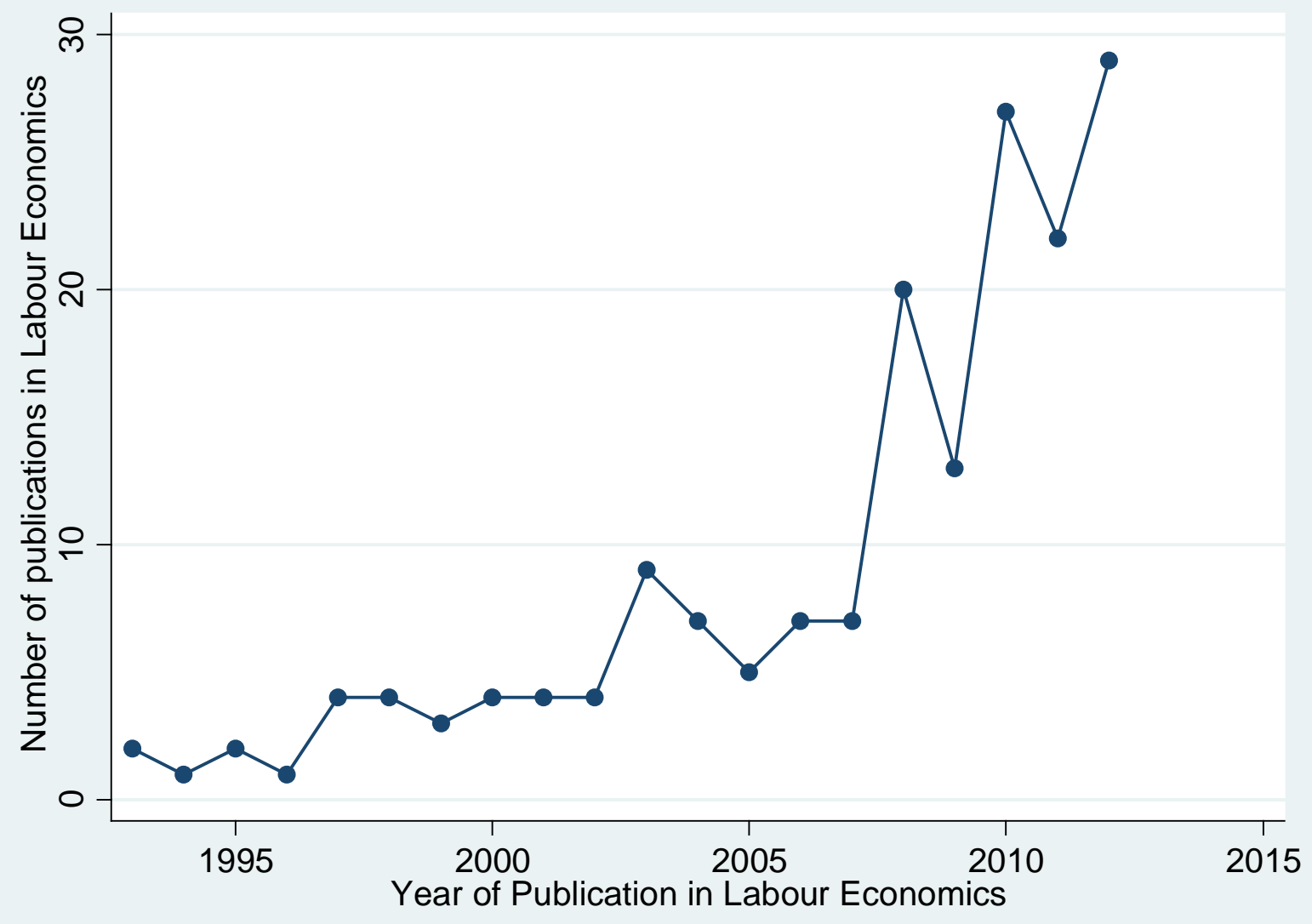

Notes: Source: Information retrieved from http://scholar.google.de/ on November 30, 2013; own counts 
Figure 4: Number or articles published in Labour Economics referring to preferences.

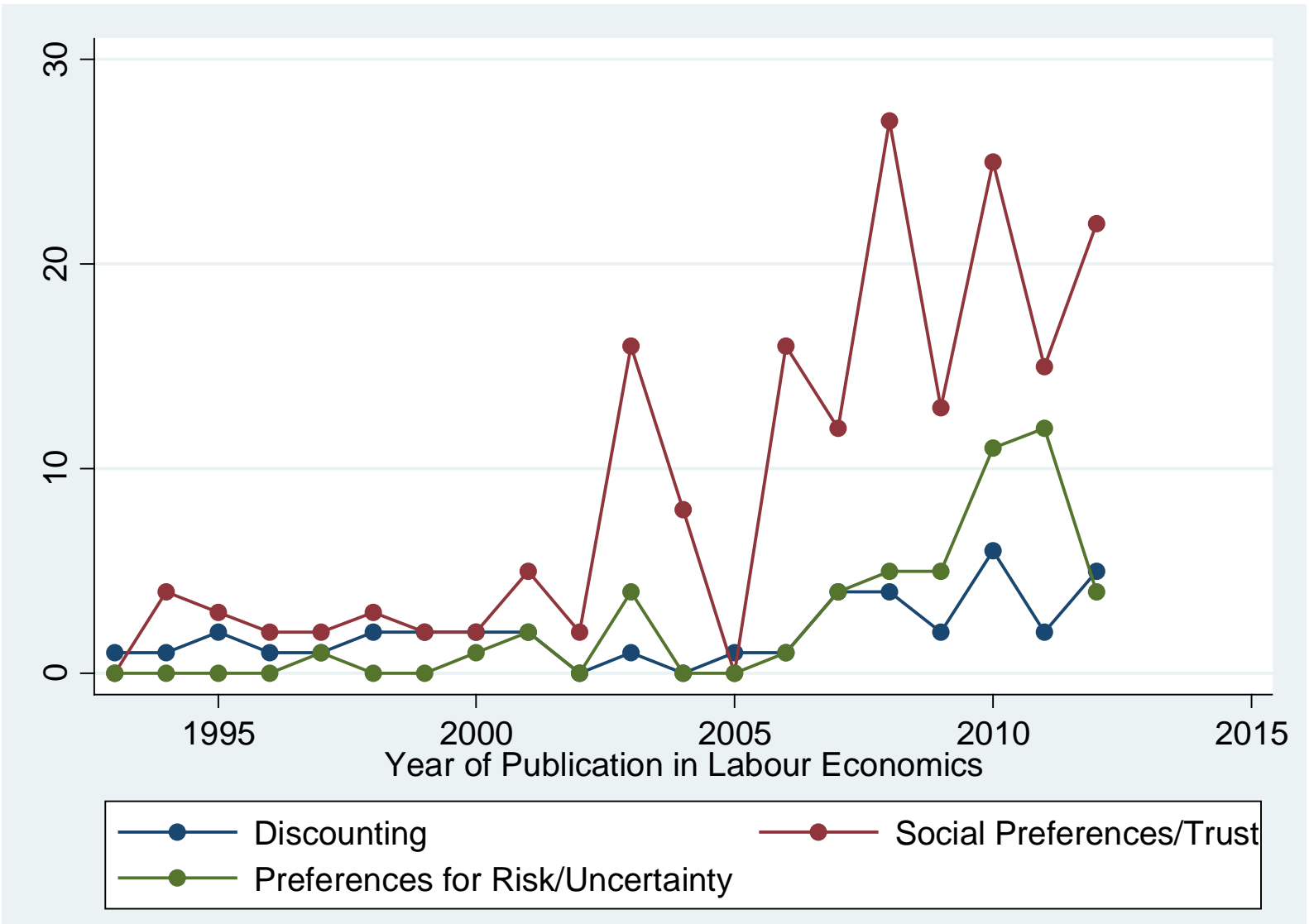

Notes: Source: Information retrieved from http://scholar.google.de/ on November 30, 2013; own counts 
Figure 5: Number of articles published in Labour Economics referring to aspects of personality

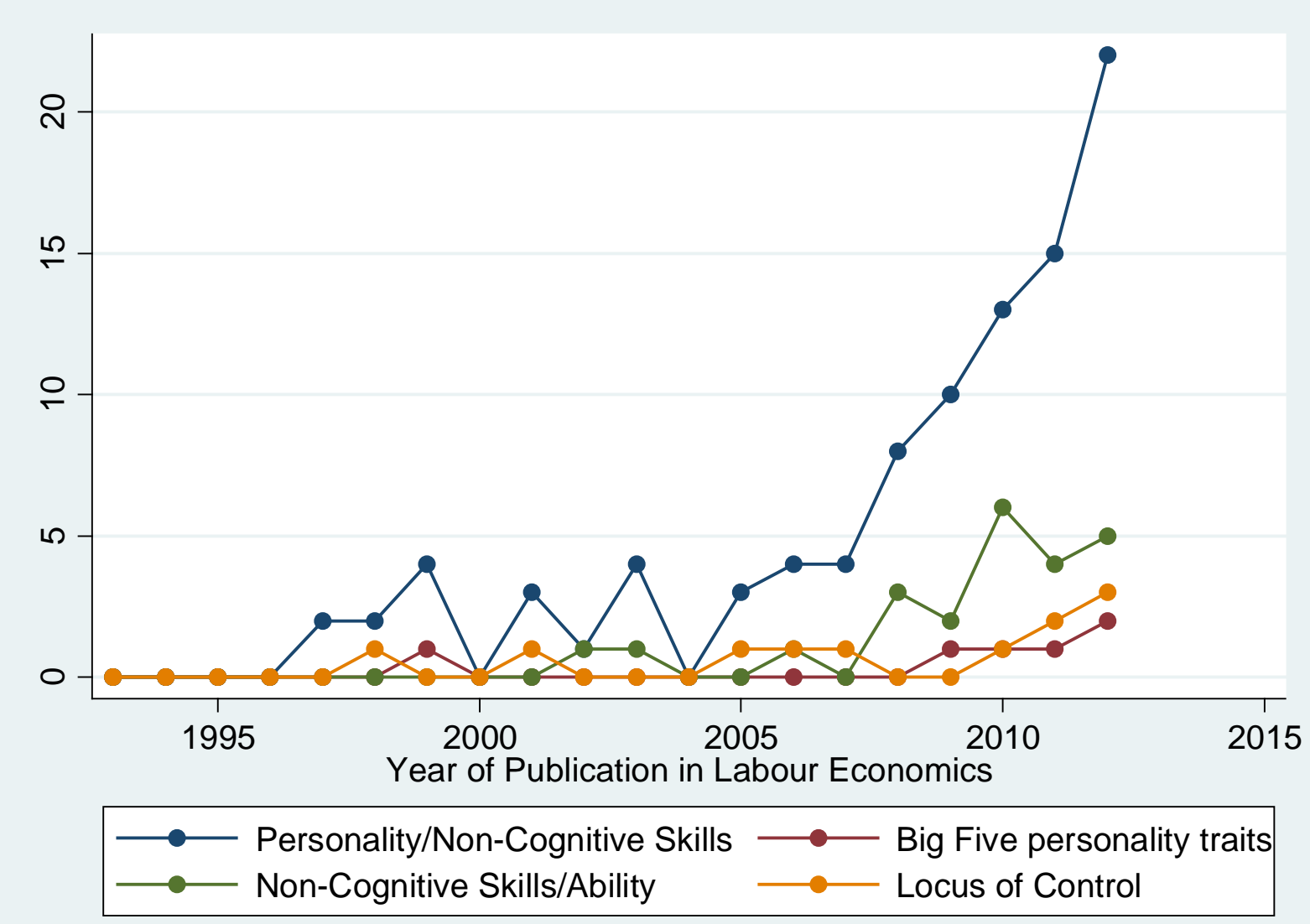

Notes: Source: Information retrieved from http://scholar.google.de/ on November 30, 2013; own counts 